\title{
6 Economic Actors in Early Imperial China
}

\section{Introduction}

This chapter examines various types of actors in the Qin 秦 and Han 漢 empires that played major parts in different kinds of economic activities. For some of these actors, one major economic role stands out in comparison to others, such as consumption in the case of imperial elites, production in the case of primary and craft producers, or distribution in the case of traders. But all types of actors are characterized by more complex patterns of behavior. For instance, members of local elites could be large-scale producers, but were at the same time essential consumers and redistributors of wealth. Local government institutions played important roles in all three aspects, and additionally acted as coordinators of economic behavior and as nodes between different types of economic actors. Households, as fundamental units of production and consumption, took over the essential function of organizing and coordinating their members' labor. The military was primarily a massive consumer, but also played an essential part in enhancing long-distance connectivity. And finally, diplomatic delegations acted as important vectors of interaction in inter-imperial politico-economic relationships. ${ }^{1}$ In the interplay with the economic 'tools' (ch. 11), the socioeconomic roles of all of these actor groups shaped the larger structures and dynamics of the early imperial economy as a whole (ch. 15).

\section{Imperial Elites}

\section{II.1 The Emperor and the Court}

\section{II.1.1 Consumption, Production, and Redistribution}

As the ruler on high takes delight in novelties, extravagant clothing is adopted among the people below. As the ruler on high treasures the goods from distant lands, wealth flows out-

1 In contrast to the chapters on economic actors of other regions discussed in this volume, this chapter does not include a section on cities as actors. In contrast to cities of certain other parts of the ancient world, it is hard to fathom cities in early imperial China as corporate bodies that, as such, 'acted' economically. Certainly, this does not mean that early imperial Chinese towns and cities were economically unimportant. If not as corporate 'actors,' they were essential in their role as containers for concentrated economic activity. Just like in other parts of the ancient world, their sheer demographic size made cities serve as network hubs of production, consumption, and distri-

Note: I would like to thank Armin Selbitschka for valuable comments on an earlier draft of this chapter.

D Open Access. (C) 2022 Kathrin Leese-Messing, published by De Gruyter. (c) BY-NC-ND This work is licensed under the Creative Commons Attribution-NonCommercial-NoDerivatives 4.0 License.

https://doi.org/10.1515/9783110607642-009 
ward. Therefore, the kingly one does not value useless things, so to set an example of thrift to his subjects; does not love exotic articles, so to enrich his country.

夫上好珍怪，則淫服下流，貴遠方之物，則貨財外充。是以王者不珍無用以節其民，不 愛奇貨以富其國。2

The true gentleman, while checking excess, would disapprove of parsimoniousness. Parsimoniousness leads to narrowness ... If palaces and houses are not decorated, the timber supply will be over-abundant ... Without the embroidered ceremonial robes, the seamstresses will have no occupation.

君子節奢刺儉, 儉則固。[...] 不飾宮室, 則材木不可勝用, [...] 無䊇䟵, 則女工不施。3

The first quotation, voiced by the 'learned scholars' (wenxue 文學) in the Former Han work Discourses on Salt and Iron (Yantie lun 鹽鐵論), ${ }^{4}$ implies more than anything else that the Han emperor at whose court they were debating did not actually adhere to a 'kingly one's' modesty. The second, expressed by the 'grandee,' who is shown as the former's opponent in this dialogic work, indicates that others saw imperial luxury in a much more positive light, for instance, as an economic stimulus. ${ }^{5}$ Similar to other ancient societies, consumption at the very top of the Qin and Han social hierarchy was intrinsically linked to the legitimization of power. Transmitted works of the Han period contain various norms and many records of people's criticism or advocacy of imperial consumption. Archaeological evidence from tombs has provided further evidence for the central power holders' role as consumers and redistributors. ${ }^{6}$

In general, the emperor himself was not meant to be a 'public person.' Contemporary ideals associated good rulership with invisibility rather than visibility. Except for high dignitaries and courtiers, even court members were not supposed to see the emperor with their own eyes, let alone the common people on the streets of Xianyang 咸陽, Chang'an 長安, or Luoyang 洛陽. ${ }^{7}$ Accordingly, in the capital cities of the Qin and Han Empires, one would have looked in vain for imperially sponsored buildings in service to the emperor's public appearances and the gathering of

bution, which stimulated specialization and labor distribution. On the importance of cities, see, for instance, Leese-Messing, ch. 15, III.3 and IV.2, this volume.

2 Yantie lun jiaozhu 2.29, trans. Gale 1967, 16 (with modifications).

3 Yantie lun jiaozhu 3.43, trans. Gale 1967, 22 (with modifications). The second part ("If palaces ...") is indicated as a "Guanzi” 管子 quote, but is not to be found in the transmitted work Guanzi.

4 On the Yantie lun and its source value with regard to economic history, see Leese-Messing, vol. 1, ch. 12.A, 513-518.

5 For more references in ancient Chinese works to the idea of consumption as economic stimulus, see Yang 1957.

6 The tombs of the Han emperors themselves have mostly been located, but none of them has been excavated yet. Some objects found in elite tombs across and beyond the empire's territory, however, bear inscriptions indicating that imperial palaces were their primary places of consumption, and therefore offer clues to both consumption and redistribution practices at court.

7 Lewis 2007, 79-80; Ch'ü 1972, 66-69. 
crowds like the theaters or the Colosseum in Rome. Those buildings that were commissioned to display the power of Qin and Han emperors to the public, such as aweinspiring terrace buildings constructed on slopes, were designed for seclusion rather than invitation. In a similar vein, the imperial palaces at the capital were hidden behind immense walls. It was the palaces' very seclusion, along with their sheer dimensions - they covered two thirds of the vast surface area of the walled city ${ }^{8}-$ which proclaimed that the most sublime of all earthly powers resided here. ${ }^{9}$

The palaces did not only consist of private chambers and administrative offices for the people who resided or worked at court on a long-term basis, however. They also comprised semipublic interior spaces for court guests - such as members of the political and noble elites or foreign rulers and delegations - at imperial audiences, ceremonies, and banquets. ${ }^{10}$ Of course, these spaces offered obvious opportunities for the display of wealth and conspicuous consumption - not for the excluded general public but for explicitly privileged groups. Both textual and (though scarce) archaeological evidence attest to their luxurious furnishing and decoration. ${ }^{11}$ People of the Han court at Chang'an were well aware that their capital city had the potential to impress visitors, particularly those coming from afar. Envoys from Anxi 安息 (the Arsakid Empire) and the Wusun 烏孫, for instance, were reportedly very impressed by the wealth of the Han Empire during their visits to the capital and therefore changed their attitude and conduct toward the Han. ${ }^{12}$

Apart from the investments into the construction and furnishing of the hundreds of buildings, the daily maintenance of the imperial court and its appendages, including several huge palaces, the emperor's harem, and the Imperial Academy (Taixue 太學) with allegedly up to 30,000 prospective scholars at its height, demanded fuel, personnel, clothing, and food - from basic staples up to exquisite delica-

8 The whole city covered an area of ca. 36 sq. km intra muros. Pirazzoli-t'Serstevens 2010, 171, 173174.

9 For an extensive treatment of the particularities in the display of power in the early Chinese empires in comparison to the Roman Empire, see Lewis 2015b.

10 After the Han dynastic founder, Liu Bang, had criticized his chancellor Xiao He for spending too many resources on the construction projects in the new capital during a time when their power base was not yet stable, Xiao He reportedly taught him the following: "It is precisely because the fate of the empire is still uncertain that we must build such palaces and halls. A true Son of Heaven takes all within the four seas to be his family. If he does not dwell in magnificence and beauty, he will have no way to manifest his authority, nor will he leave anything for his heirs to build upon." 天下方未定, 故可因遂就宮室。且夫天子四海為家, 非壯麗無以重威, 且無令後世有以加也。Shiji 8.385386, trans. Lewis 2007, 92-93.

11 Barbieri-Low 2007, 153-211, offers an illustrative impression of what we know about the palaces' interior decoration and furnishing, as well as of the craftmanship involved.

12 Shiji 123.3169; 3171-3172, trans. Watson 1993, 239-240, 243; Nienhauser 2019, 77, 83. Emperor Wu also took foreign visitors on tours to other parts of the empire, showing off the empire's size, its huge storehouses, and populous cities, and regaling them with luxurious accommodations and gifts (Shiji 123.3173, trans. Watson 1993, 244). 
cies, some of which were imported over long distances. Lychee and Longan fruits, for instance, were transported to the court as tribute from the tropical southern regions of the empire, requiring high-speed delivery to keep them fresh. Their consumption at court was an object of criticism on several occasions during Later Han times. ${ }^{13}$

Outside the Former Han capital of Chang’an, Shanglin 上林 Park was another place intrinsically connected to imperial power display and large-scale consumption. First established by the First Emperor of Qin and massively extended by Emperor $\mathrm{Wu}$ 武 (r. 141-87 BCE) of Han, it mainly consisted of a large wilderness preserve for imperial hunts and excursions. Invitations to take part in such events were regarded as an exclusive honor. According to several transmitted texts, Emperor Wu had the park equipped with all kinds of luxuries and curiosities, many of which (such as flora and fauna of foreign origin) stood out on account of their exotic nature and thus had a direct link to imperial expansionism. The park also comprised, among others, palatial edifices equipped to host high-level and large-scale imperial banquets that reportedly could, at least during Qin times, host up to 10,000 guests. ${ }^{14}$ An integral part of such gatherings was the bestowal of lavish gifts upon the guests, typically in the form of exclusive, high-value products from imperial workshops. ${ }^{15}$ After all, the ability to cause multitudes of people to travel from afar and pay their respect to the 'Son of Heaven' (tianzi 天子) was yet another central aspect of traditional rulership ideals. ${ }^{16}$ The massive distribution of gifts, along with the luxury tableware and exquisite food consumed both at feasts and in daily life at court, must have considerably driven the imperial demand for these goods. The same is true for the vast amounts of gifts that were exported in the context of foreign diplomacy. Under the name of the emperor, exquisite silk, as well as bronze, lacquer, and other items, were transported in massive quantities to the political centers of the empire's neighbors, especially the Xiongnu 匈奴 Empire. These imperial gifts were meant to build up or maintain friendly relations, which were expected to bring both peace and, in some cases at least, valuable gifts in return. ${ }^{17}$

Many of the luxury items (among others) are known to have been produced in imperial workshops officially run under the ownership of the emperor. The latter, therefore, also played a central role in the processes of state production. Imperial workshops were located both in the capital and across the empire. The locations of the facilities were often inherited from pre-Han times, with both local production traditions and availability of raw materials playing important roles. Sichuan, for instance, hosted the most prestigious imperial workshops for the production of lac-

13 Yü 1977, 80, with the according references from transmitted sources.

14 On Shanglin Park, see Lewis 2006, 171, 177-178; Hung 1995, 170-176.

15 Barbieri-Low 2001, 6-7.

16 Lewis 2007, 89.

17 On this form of long-distance exchange, see also sec. $\mathrm{X}$ below. 
quer items consumed and redistributed at court, in a continuation and enhancement of centuries-old local traditions. ${ }^{18}$ And one of the most famous imperial production centers for textiles, the 'Three [Seasons] Garments Office' (San fu guan 三服官), was located in the commandery of Qi 齊 in the empire's far east. ${ }^{19}$ Certainly, the manifold demands created by court consumption and redistribution practices did not only rest on state production but also involved procurement of both raw materials and finished products on the market. This aspect is, however, much less visible in our source material and is only beginning to be thoroughly investigated in scholarship. ${ }^{20}$

As in the case of exotic animals and plants mentioned above, imperial consumption patterns also included a certain demand for imported goods. Some emperors are particularly famous for their fondness of foreign products. Some of this demand was - at least initially - based on pragmatic considerations, such as in the case of Emperor Wu's eagerness to acquire Central Asian (and particularly Dayuan 大宛) horses for his army. ${ }^{21}$ But consumption of certain foreign products also played a role in more private imperial spheres. Emperor Ling 靈 (r. 168-189 CE) of the Later Han, for instance, is said to have had a particular soft spot for foreign items of daily use. He is said to have been fond of products originating from the empire's northern neighbors, such as "Hu clothes, $\mathrm{Hu}$ curtains, $\mathrm{Hu}$ beds, $\mathrm{Hu}$ seats, $\mathrm{Hu}$ food, $\mathrm{Hu}$ lutes, and Hu flutes” 胡服、胡帳、胡牀、胡坐、胡飯、胡空侯、胡笛. 22

An important sphere in which the very idea of rulership demanded extensive consumption was the sphere of mortuary practice, ancestry cult, and services to super-human powers. The forms of practicing these cults, including their objects of worship (e.g., deities or certain mountains), their places, and their dimensions, changed considerably over time. Consideration of costs, but also of changes in popular religious beliefs, could play a role in such reforms. ${ }^{23}$ Some of the rituals demanded extensive traveling. For Emperor Wu's first performance of the newly introduced fengshan 封禪 sacrifices at Mount Tai (Taishan 泰山) in the east, which he combined with visits to other places as well, he reportedly traveled 18,000 li

18 On the distribution of Han imperial workshops across the empire, see Barbieri-Low 2001, 4194. For the Sichuan lacquer workshops in particular, see Barbieri-Low 2001, chs. 3-5; BarbieriLow 2007, 186-188. See also Leese-Messing, vol. 1, ch. 12.C. For the pre-imperial centers of lacquer production, see Thote 2003.

19 In today's Shandong province. See, for instance, Hanshu 72.3070; Kuhn 1995, 103-104.

20 On some evidence for the relevance of markets to satisfy state demand for various products (e.g., textiles), see further Leese-Messing, ch. 15, III.1, this volume.

21 The demand for horses figures prominently in Sima Qian's 司馬遷 (145 or 135-ca. 87 BCE) account on Dayuan, Shiji 123, trans. Watson 1993, 231-258; Nienhauser 2019, 54-104.

22 Hou Hanshu 13.3272 (treatises section). The designation 'Hu' 胡 often referred to the Xiongnu in particular, but was also used in a broader sense, then referring to various neighbors in the steppe region to the Han Empire's north.

23 Loewe 1974, ch. 5, 1992; van Ess 1993, 182-184. 
(ca. 9,000 km). ${ }^{24}$ Such trips, which he undertook several times, demanded considerable preparation by the officials and other people of the places to and through which the emperor traveled, for instance with regard to the maintenance of roads. ${ }^{25}$ Emperor Wu's undertakings in this regard were, however, rather exceptional among Han emperors.

It may be debated how far the emperors' often lavish expenditures in these domains could be interpreted as 'conspicuous consumption' and rational 'investment' in power preservation, i.e., a conversion of economic power into political power. While some of the practices - like funerary processions and regular ritual ceremonies at the emperors' shrines - involved a certain amount of public participation, ${ }^{26}$ others were conducted in strict secrecy. ${ }^{27}$ Qin Shihuang's enormous tomb complex may serve as the most illustrative example to show that publicity did not always play the central role: The thousands of life-size terracotta warriors and all the other luxurious inventories that have so far been unearthed from his necropolis, which covers an area of almost $100 \mathrm{~km}^{2}$, are a breathtaking sight today, but they were not meant to be marveled at by contemporary passersby. They were, after all, buried underground. ${ }^{28}$ Irrespective of the question of publicity, one may ascribe some wider economic impact to this kind of mortuary consumption. It established,

24 Hanshu 25A.1234-1236. Mount Tai is located in modern Shandong.

25 Van Ess 1993, 183.

26 The sources often do not give a clear picture of the extent of publicity involved in such events. Other than during later (i.e., Tang) times, ceremonial processions conducted by the emperor during Han times often appear to have been open to be witnessed by commoners (Nylan 2005, 48, n. 128). Loewe suggests that the monthly ceremony during which "the robes and headdress of the deceased emperor were conveyed from the rest chamber to the shrine" was an event that "may have attracted crowds of onlookers." He further suggests that imperial shrines may have belonged to the "few ... great buildings with which the general public would have had direct contact" (Loewe 1999, 91, 99). A historical record of Emperor Ming 明 of the Later Han (r. 58-75 CE) practicing the ritual of plowing the ceremonial field in $69 \mathrm{CE}$ mentions (otherwise unspecified) “spectators” (guanzhe 觀者) whom the emperor served food after the ritual (Hou Hanshu 2.116). Invited guests were definitely present at many occasions, such as imperial funerals and sacrifices.

27 One famous example being Emperor Wu's performance of the feng and shan sacrifices at Mount Tai, which was largely connected to his private quest for immortality (Loewe 1974, 184-185). But, whereas the ceremony itself was secret, the emperor's travelling to the mountain did have ample potential for public arousal.

28 Even though the tomb inventories were not seen after their burial, people may have gotten information on them, and thus, have marveled at their number, etc., without seeing them personally. Sima Qian, for instance, obviously knew about some of Qin Shihuang's lavish tomb inventory, and his knowledge may have derived from archived documents or some other form of information that had been made public. See Shiji 6.265, trans. Nienhauser 1994, 155. Nevertheless, both costly rituals and construction projects could also serve private rather than public means, as in the case of certain emperors' dreams of immortality. In comparison to Qin Shihuang, Han emperors seem to have been 'modest' with regard to their tomb inventory, but their expenses were nevertheless substantial. 
for example, a substantial demand for mass production of certain funerary products, such as funerary figurines and, particularly during Later Han times, tomb bricks. ${ }^{29}$ In the case of imperial tombs, most of these goods were probably produced in government-owned workshops rather than acquired on the open market. ${ }^{30}$ Nevertheless, the mortuary mass culture associated with imperial entombments left a mark on production and logistical techniques that, through processes of elite emulation, became widespread phenomena in both a geographical and a social sense and are likely to have had spillover effects on other branches of production as well. ${ }^{31}$

Former Han emperors' tombs had yet another kind of economic impact: Each tomb's construction in the larger surroundings of the capital city of Chang'an was accompanied by the establishment of an entire new town right next to the tomb. Such so-called 'tomb towns' were filled with inhabitants by the forced resettlement of hundreds of thousands of people from the eastern part of the empire. In theory, these people were seen as the guards and maintainers of the tombs, but for practical purposes, resettlement dispossessed many wealthy and powerful people of their local resource bases and networks in the east and made them more manageable in a nearby place. Furthermore, the capital region needed manpower in many fields, such as construction and administrative work. ${ }^{32}$ Several of these tomb towns eventually belonged to the largest and most populous cities of the whole Han Empire, and therefore substantially changed the metropolitan area's economic role, especially with regard to urban consumption. ${ }^{33}$

Apart from the production of burial objects and the construction of the tombs ${ }^{34}$ with their accompanying tomb towns, it was the long-term costs of ancestor worship in particular that made mortuary practice a matter of enormous expenditure on behalf of the emperor on a regular basis. During the rule of Emperor Yuan 元 of Former Han (r. 48-33 BCE), services to the imperial ancestors at altogether 176 sites $^{35}$ reportedly required the offering of 24,455 meals annually and employed 45,129 service-

29 Or even mass-produced statues, in the case of the First Emperor of Qin, for which see Ledderose 2000, ch. 3 .

30 Archaeological excavations at the site of the Former Han capital Chang'an have brought to light remains of kilns that produced funerary pottery figurines at a massive scale. Zhou and Wang 1985; Zhongguo shehui kexueyuan kaogu yanjiusuo Hancheng dui 1994. On the role of funerary figurines in ancient Chinese burial culture, Selbitschka 2015b.

31 On mass and modular production in ancient China, including techniques following the socalled 'assembly line' or 'conveyor principle,' see Barbieri-Low 2007, 73-101; Ledderose 2000.

32 Korolkov and Hein 2020, 10.

33 On the tomb towns, see Loewe 2017, 2015; Yu and Li 2012.

34 Ideally, the construction of an emperor's tomb was supposed to be started in the year after his accession and involved, among others, the erection of a huge, artificial tumulus, which housed many underground chambers and corridors. See Loewe 1999, 87.

35 The main shrines were those near Chang'an, but many more had been established at places far away from the capital to which some of deceased emperors had travelled. 
men, 12,147 prayer-reciters, cooks, and musicians, not even counting those people that were deputed to tend the sacrificial animals. ${ }^{36}$ The costs for mortuary practices, which also included state funerals for imperial relatives and high statesmen, and ceremonies held at the ancestral temple must therefore be considered as one of the largest expenditures of the emperor's privy purse.

\section{II.1.2 Extraction}

The finances of the Former Han government were split between two purses: a public purse under the control of the superintendent for agriculture ( $d a$ sinong 大司農), on the one hand, and the so-called 'Lesser Treasury' (or 'Privy Purse,' 'Ministry of Resources,' Shaofu 少府), on the other. The fields of extraction and expenditure of the two were not always strictly separated and partly changed over time. But generally, it was the Lesser Treasury that was responsible for most of the expenditure associated with the person of the emperor, i.e., court consumption (including furnishings, clothes, food, and entertainment), imperial tomb furnishings (though not the construction of the tombs themselves), and the massive amounts of gifts handed out to officials, nobles, and foreign rulers. ${ }^{37}$

The sources of revenue for this branch mostly included commercial taxes, which accounted for an estimated half of its budget. To a much lesser degree, they also comprised the poll tax on children, seigniorage, and tribute taxes (paid by nobles in gold). Furthermore, they comprised income from the products of the socalled 'mountains and marshes.' Among others, this included revenues from government-owned lakes and ponds but most importantly from the salt and iron industries. During the first century of Han rule, these were extracted as taxes, and are likely to have contributed the major part of the Lesser Treasury's budget. When Emperor $\mathrm{Wu}$ established the salt monopsony and iron monopoly, he transferred their enormous revenues to the public purse, i.e., the Ministry of Agriculture, which was at that time in dire need of new revenues for the expansionist wars. ${ }^{38}$ The emperor also owned agricultural lands, most of which seem to have been located in the region around the capital. But since the available sources do not enable us to determine their size, or even if they grew or diminished over time, it is hard to

36 Loewe 1992, 324.

37 The Ministry of Agriculture extracted its income mainly from the field tax and the adult poll tax, by which it financed officials' salaries, infrastructural investments, and military defense. See Leese-Messing, ch. 11, II, this volume.

38 For further details on the revenues from the salt and iron industries, see Leese-Messing, ch. 11, II.3.5. The taxation of natural resources during the time before the establishment of the monopolies has become clearer with the find of an according legal statute among the Zhangjiashan corpus. See Barbieri-Low and Yates 2015, 916-19, 926-27 (no. 12 of the "Statutes on Finance," slips 436-38). 
fathom their economic relevance. According to Yamada's estimate, their revenue accounted for little more than a tenth of the Lesser Treasury's income. ${ }^{39}$

In general, therefore, expenditure associated with the person of the emperor was largely funded through taxes. In comparison to Roman emperors, for instance, they were based to a much lesser extent on income generated by the emperors' imperial estates. Things become more obscure with regard to Later Han times, when private and public purse were merged under the superintendent for agriculture's ministry. This blurred the distinction between the two financial branches, which likely facilitated abuse of financial resources. ${ }^{40}$

\section{II.1.3 Imperial Consumption as a Model for Elite Emulation}

Even though many aspects of court consumption and redistribution were connected to 'in-house' production via state-owned facilities, their economic impact was felt in much wider circles through elite emulation. The importance of the latter is clearly suggested both by many textual references (such as the critic's warning quoted at the beginning of this section) and by archaeological evidence. Critics of lavish consumption often bemoan a “competition in excess and extravagance” 競於淫靡, ${ }^{41}$ and imperial subjects "emulating [the emperor's] model of excess, so that their clothing, footgear, and ornamented arms have become confusingly like those of the emperor." 42 The source of the latter quote further complained to the emperor that on a trip to the empress's palace he was "presented with lacquer cups and trays, all of which had painted decoration and gold and silver mounts," which were "not appropriate objects with which to present a subject to sup upon." ${ }^{43}$ Lacquer tableware is a very clear example of elite emulation. Tombs of kings and local elites often contain a mixture of lacquer objects evidently produced in imperial workshops (likely gifted by the emperor on occasions like the previous example) and lacquer objects made in other, possibly 'private' workshops. Barbieri-Low has further called attention to a lacquer platter that bears all signs of a privately produced piece and even gives the family brand name of the private producer in its inscription. At the same time, this very inscription starts off by claiming that the platter was made in one of the famous imperial lacquer workshops, a fake branding, if you will, which is unthinkable without the phenomenon of emulation. ${ }^{44}$

39 Loewe 1985, 249. Von Glahn 2016, 117, based on Yamada 1993, 653-658.

40 Bielenstein 1980, 46, 55, 67-68.

41 Yantie lun jiaozhu 3.42, trans. Gale 1967, 21, with modifications.

42 臣下亦相放效, 衣服履絝刀劍亂於主上。Hanshu 72.3070, trans. Barbieri-Low 2001, 407.

43 見賜杯案, 盡文畫金銀飾, 非當所以賜食臣下也。Hanshu 72.3070, trans. Barbieri-Low 2001, 408, with modifications.

44 Barbieri-Low 2007, 142-145. On the social aspects of emulation more generally, and its role in silk consumption patterns as suggested by burial finds in the Tarim Basin between the second and fifth century CE, see Selbitschka 2018a. 
Emulation processes at court most likely also contributed to a wider spread of demand for foreign products in high elite circles. As a result of Emperor Ling's fondness of 'Hu' products, for instance, "all the members of the imperial relatives at the capital competed in imitating him” 京都貴戚皆競為之. ${ }^{45}$ Earlier, according to transmitted letters, the court historian Ban Gu 班固 (32-92 CE) asked his brother Ban Chao to procure certain foreign products for him that were available in the Tarim Basin, where the latter was stationed as a high military official and protector-general of the Western Regions (Xiyu duhu 西域都護). The products mentioned in their correspondence include exquisite Yuezhi rugs, storax incense, and horses, and one letter mentions Ban Chao's purchase, on behalf of his brother, of a multicolored woolen tapestry from the Yuezhi worth 800,000 coins. ${ }^{46}$ That demand for foreign and exotic-looking products of daily use was neither restricted to the capital nor to the time of Emperor Ling's reign has been amply demonstrated by finds in tombs belonging to the kings in the east. ${ }^{47}$

\section{II.2 The Imperial Family}

Economic processes that centered on the person of the emperor alone do not tell the whole story of the economic roles of the imperial elite. Many more aspects could be added here to diversify the picture, two of which will be touched upon in the following. Most generally, kings acted as important nodes of the imperial network through which certain imperial consumption and production processes were extended far beyond the central court. Broadening our field of vision further to include female members of the imperial family shows that active involvement in economic processes happened across gender roles.

\section{II.2.1 Kings in the Eastern Part of the Empire}

Except during the very first years of the Former Han dynasty's rule, Han kings (wang 王 or zhuhou wang 諸侯王) were almost exclusively members of the Liu ruling family. ${ }^{48}$ Kingdoms (wangguo 王國) and the associated titles were usually granted to an emperor's sons. The kingdoms were all located in the eastern part of the empire, many hundreds of kilometers away from the Former and Later Han capital cities. The substantial administrative and economic power of the kings was drastically

45 Hou Hanshu 13.3272 (treatises section).

46 Quan Hou Han wen 25; Z. Wang 2018, 18.

47 See the following section.

48 One of the exceptional examples of "kings of a different surname" (yixing wang 異姓旺) was Zhao Mo 趙眜, King of Nanyue 南越, whose body was also vested in a jade suit (on which see below). 
curtailed through a number of measures during the first century of Han rule, including the integration of the local kingdoms' administration and taxation into the centralized system and a drastic reduction of their territories. ${ }^{49}$

However, kings continued to enjoy considerable privileges, especially with regard to imperial gifts and sumptuary rules, which defined their economic roles as consumers. ${ }^{50}$ These privileges are particularly evident in kings' tombs. Other than those of Han emperors, dozens of Former Han kings' tombs have been excavated during recent decades. Instead of the formerly common assemblages of bronze ritual vessels known from Warring States elite burials, Han kings' tombs increasingly exhibit finely decorated items of daily use, particularly exquisite banquet equipment (including tables and tableware, typically lacquered), lamps, incense burners, and (at times immense amounts of) coins, but also horses, chariots, weapons, and ceramic or wooden miniature figurines, including those of different kinds of servants. One example of the highly exclusive components of the kings' burials are the jade suits holding the kings' and their consorts' bodies, which consisted of thousands of jade plaques sewn together with silk or gold threads. ${ }^{51}$ Reportedly, their mausoleums were each accompanied by an adjacent tomb settlement, albeit on a much smaller scale than those of the emperors. ${ }^{52}$

Interestingly, rather than showing signs of redistribution from the center of imperial power, many of the lacquer objects found in kings' tombs bear inscriptions that suggest they were produced locally, possibly in workshops that stood under the control of individual kings themselves. ${ }^{53}$ Apart from their role as consumers and in the redirection of resources from the center to the east, some kings may thus have been actively promoting local luxury production as well.

What the tombs also reveal is some of their occupants' appreciation of foreign products, including both actual steppe imports and objects adopting steppe-style forms or elements. Typical examples are imported gold or gilt bronze belt plaques and locally produced jade plaques. ${ }^{54}$ Obviously, this appreciation for foreign products and styles was something that they shared with at least some of the Han emperors. In the context of local production, the adoption of 'exotic' styles and motives may have promoted the creation of new product niches and specialization opportunities, even if the items were produced only for high elite consumers. Furthermore,

49 On the changing role of the kings, see also Leese-Messing, vol. 1, ch. 4, 153.

50 Apart from the archaeological evidence from tombs, on which see below, transmitted historical texts frequently mention certain kings' extreme wealth and extravagant consumption habits. Loewe 2010, 306-307.

51 On the kings' tombs and tomb inventories, see Rawson 1998, 1999.

52 Hanshu 63.2748 gives the number of 300 families as the standard population of a king's tomb settlement.

53 Y. Liu 2019a, esp. 50-56.

54 Kost 2017, also providing a map and a list of the royal tombs including such objects (352 and 356). See also Rawson 2012. 
extended demand for such products in these high elite circles is likely to have fostered the import of actual foreign goods. This raises the question of whether foreign products were imported via market structures and long-distance trade or whether their influx was related to the central governments' diplomatic exchanges. The latter would imply that their distribution was mostly confined to the network of the emperor and his closest family members. Although future research and new archaeological evidence may provide new clues on this matter, so far foreign products, and even the adoption of foreign styles, have almost exclusively been found in royal tombs, favoring the diplomatic exchange model.

\section{II.2.2 Empresses, Empresses Dowager, Queens, and Princesses}

Empresses and empresses dowager were often among the most powerful political actors at court, with some of them even superseding the emperor's influence. But apart from their undoubtable wealth, which included landholding, we do not know many details about the economic roles of female members of the imperial family. Individual passages in transmitted texts suggest, however, that their potential with regard to decision-making in economic matters was quite substantial. Reportedly, for instance, the powerful Empress Dowager Dou 竇 (d. 135 BCE) ${ }^{55}$ bequeathed all the monetary and material belongings from her palace to her daughter instead of a male heir. ${ }^{56}$ In a similar vein, a Former Han princess successfully fended off a government official's attempt to compell her deceased husband's (i.e., the former king of Changshan's 常山) sons to share their inheritance with a dispossessed sibling. ${ }^{57}$ And under Emperor Jing 景 (r. 157-141 BCE), an imperial princess, probably the latter's elder sister Liu Piao 劉嫖, personally decided to financially aid her late father's (i.e., Emperor Wen's 文, r. 180-157 BCE) former courtier Deng Tong 鄧通 after the latter had been dismissed from court and deprived of his gigantic holdings. ${ }^{58}$ All these instances show that female members of the imperial family likely played a much more active role in various economic distribution processes than a first impression might suggest.

\section{Local Elites}

\section{III.1 Generation of Wealth and Agriculturalist Self-Presentation}

Han society and its local elites in particular evolved on the basis of what might be termed a phase of 'creative destruction' during several war-intensive centuries be-

55 She had been the wife of Emperor Wen 文 (r. 180-157 BCE).

56 Shiji 49.1975. On this and the following case, see also Hinsch 1998, 17; Z. Liu 1980, 146.

57 Shiji 59.2102-3.

58 Shiji 125.3193, trans. Nienhauser 2019, 137. 
fore the Qin unification. By the end of the Warring States period, the old hereditary aristocratic system had been largely dissolved, and it was finally brought to naught during the early Han period. ${ }^{59}$ Along with the simultaneous development of a market in land, this bore the potential for new local elites to arise whose power was largely built on wealth. ${ }^{60}$ It is known especially with regard to the early Former Han period that some people became tremendously rich as entrepreneurs, particularly in the lucrative, pre-monopoly salt and iron industries. ${ }^{61}$ But in general, the economic, social, and ultimately also political power of local elites in Han China mostly rested upon landholding. Landholders may have profited further from the introduction of certain new agricultural tools and technologies, which are likely to have been disproportionally advantageous to elite landowners who could provide sufficient capital for the required investments. ${ }^{62}$

Creating wealth on an agricultural basis was necessarily connected to a certain degree of commercial enterprise. But generally speaking, agriculture was viewed as a much more honorable way of making a living than any kind of commercial, especially mercantile activity. In a way similar to other ancient societies, this mindset certainly promoted wealthy people's investment in land, on the one hand, and delegation (and thus, concealment) of fundamental commercial tasks, on the other. ${ }^{63}$ In early imperial China, it likely further contributed to elite members' tendency to present themselves in rural-agricultural rather than urban-mercantile contexts, with the latter probably being underrepresented in our source material. As explicated in further detail elsewhere, urbanity was not at the core of local elites' identities. ${ }^{64}$

\section{III.2 Local Elites and the State}

The Former Han dynasty saw the formation of large estates with sizes not necessarily dependent on the owner's position in the official state hierarchy. In the early period, many of the new local magnates may not have played any role in the state

59 That the length and intensity of wars were the central crucial factor for the downfall of the old nobility and for the establishment of efficient bureaucratic institutions, has been most strongly put forward by Kiser and Cai 2003. On these pre-imperial developments, see also Leese-Messing, vol. 1, ch. 4, 133-138.

60 The development of a new elite during the Former Han dynasty shows up in the Scribe's Records (Shiji 史記) as one of the phenomena that the historian Sima Qian was most interested in (and concerned about). See van Ess 2014.

61 See the examples that Sima Qian mentions in Shiji 129, trans. Watson 1993, 433-454; Nienhauser 2019, 261-309.

62 Ebrey 1986, 618. On these technological novelties, see further Leese-Messing, ch. 11, VII, this volume. On landlords, see further sections V.1 and VI below.

63 For parallels in other ancient societies, see, e.g., Fabian and Weaverdyck, ch. 3.A, VI.1, this volume.

64 See Leese-Messing, ch. 15, III.3, this volume. 
administration at all. For several decades, these people's accumulation of land and other property was not a central concern of the central government, which was still very much occupied with the consolidation of its own administrative structures and curtailing the power of the kingdoms in the eastern part of the empire. Under Emperor $\mathrm{Wu}$, however, the wealthy - and those relying on commercial activities in particular - came under attack because their wealth was both recognized as a threat to central authority and as a potential source for the huge expenditure underpinning new expansionist policies. Short-term measures like certain tax increases, reprisals against tax evaders, intimidation of local magnates, and expropriations of property accompanied the long-term reintroduction of state monopolies on iron and salt production, as well as on coin casting, which indeed deprived many entrepreneurial magnates of their economic base. In the long run, these restrictions regarding some of the most profitable means of private capital accumulation must have made investment into land even more attractive. ${ }^{65}$

Over the course of the Former Han period, local elites increasingly integrated themselves into the bureaucratic system. The state needed increasing numbers of officials, and the local elites wanted to be part of the decision-making processes on local, regional, and court levels, all of which could at times have important impact on their local power bases. ${ }^{66}$ Being connected to the emperor by marital ties was a particularly effective means for a local magnate's family and its extended social network to dominate court politics. ${ }^{67}$ Local networks' deputies at court successfully fought against certain measures of economic interventionism and attempts at legally limiting sizes of estates or numbers of slaves, among others. On a local level, it meant that elite families came to be deeply intertwined with local government institutions (see sec. IV below). The economic and political power of local elites, and of certain regional networks in particular, is believed to have grown even more during the Later Han period, which is typically described as a period during which increasing numbers of the farming population became tenants of large landowners and were largely wrested from the state's control. ${ }^{68}$

\section{III.3 Local Elites' Ideals, Conspicuous Consumption, and Distribution Practices}

The most esteemed qualities of local elites' self-definition included officeholding, climbing up the bureaucratic ladder, and acquiring official honorific titles. This

65 Hsu 1980, 36-43.

66 For the role of local government institutions and their interlocking with local elites, see sec. IV below.

67 On consort families, see, for instance, Ch'ü 1972, 168-174, 210-221; Wilbur 1943, 38-40.

68 On tenancy, see further sec. V.1 below. For some critical remarks with regard to generalizing views in this context, however, see Leese-Messing, ch. 15, I.2, this volume. 
view only waned to a certain degree toward the end of the Han dynasty. Scholarly education and familiarity with certain texts were not yet as central to a man's honor as they would become in later centuries, but their importance increased at least for the higher echelons of local elites, as these values were increasingly promoted by the state. ${ }^{69}$ An individual's educational opportunity depended largely on his monetary and social capital. Obviously, the latter considerably superimposed the meritocratic principles that formed the core idea of the bureaucratic recruitment system. ${ }^{70}$

More generally, local elites defined themselves through the knowledge and practice of certain ritual codes and moral values, in which hierarchical relations played a central role. One virtue that local elites increasingly emphasized was 'filial piety' (xiao 孝). This development was significantly fueled by the state's introduction of a system of local recommendations for future officials, in which an aspirant had to be recommended by a patron as 'filial and incorrupt' (xiaolian 孝廉). The most significant demonstration of filial piety in public was to throw a lavish, costly burial for one's parents. Funerary customs demanded expenditure on tomb structure building, coffins, tomb inventory, and feasting guests from near and far. Depending on the decedent's social status, these could add up to hundreds and thousands of people. ${ }^{71}$ Quite accordingly, the dynastic histories often refer to local elite members spending all their possessions on these funerals. Furthermore, according to a passage of the canonical Book of Etiquette and Ceremonial (Yili 儀禮), funerary lists, including gifts from funerary guests, were supposed to be read out loud during the ceremony. Assuming that similar procedures were indeed followed during elite burials during Han times, they offered an opportunity for both the hosts and the donors to display their spending capacity, their cultural knowledge, and their social capital in the form of their membership in a reciprocal exchange network. ${ }^{72}$

The public display aspect is also indicated by some funerary stele inscriptions that mention how many workers' labor and how much money was spent on their erection. ${ }^{73}$ The intimate interdigitation between moral virtue, public display, and wealth is illuminated by the Later Han thinker Wang Fu's 王符 (ca. 82-ca. 167 CE) sarcastic remark on contemporary funerary practice:

[People] these days disregard [their parents'] wishes and spend little to take care of them, being parsimonious during their lifetime and just waiting for them to die. After their parents

69 For some typical aspects of (male) elite self-consciousness as 'cultured gentlemen' (shi 士), see Ebrey 1986, 643-646.

70 On education, see also sec. VI.3 below.

71 Selbitschka 2018b, 192-198, convincingly argues that in contrast to some earlier suggestions, funerary feasts are unlikely to have been held inside the tomb structure, while not denying the probability of large banquets outside the tomb structure having been typical elements of the larger context of elite burials. That banquets indeed were elements of burial rites is also suggested by the passage quoted in the following paragraph.

72 Yili zhushu, 39.755-56; Cook 2006, 47; Nylan 2005, 35; Korolkov 2012, 318-319.

73 Zheng 2008. On the elites' culture of public display more generally, see also Nylan 2005, 23-37. 
have passed away, they then squander the money thus saved on sumptuous funerals in order to show off their filial piety, inviting guests to exuberant banquets in order to acquire fame.

今多違志儉養, 約生以待終, 終沒之後, 乃崇餝婁紀以言孝, 盛饗賓旅以求名。74

Commemorative steles and funerary inscriptions, some of which bear extensive lists of sponsors and their donations in cash, have provided further evidence for what constituted laudatory behavior among their peers and their practices of distributing capital. Many of the commemorated people were local officials who are praised for their public engagement, e.g., with regard to road or dike repairs, or the building of local shrines. Even holders of minor local posts are at times lauded for making huge private investments worth hundreds of thousands in cash. Some monuments also commemorate people of no official rank for their generosity, e.g., for giving out loans without pressing for repayment, for helping their community, and for collecting food for orphans. ${ }^{75}$ Many of these distribution practices are reminiscent of what is commonly referred to as euergetism in the Graeco-Roman world. ${ }^{76}$ One obvious and important difference to the typically Graeco-Roman practice was, however, that neither emperors' nor elite's benefactions were strongly associated with the funding of public urban buildings. Even though source biases may underrepresent some of their urban aspects, hitherto known charity practices indicate a focus on the rural sphere and the building of networks rooted in the countryside. ${ }^{77}$

Of course, elite consumption patterns were not restricted to festivities, funerals, and other extraordinary occasions that lent themselves to displays of piety and generosity. Countless transmitted passages of criticism indicate many other fields of consumption that enhanced investment opportunities, private convenience, and occasions for public display on a more permanent basis. Things that are typically included in enumerations of very wealthy people's favorite investments and status symbols are large and luxurious mansions, huge agricultural estates, innumerable farm animals, and hundreds or more slaves, as well as carts and carriages roaming about in all directions for the sake of their lords' mercantile interests. ${ }^{78}$

Tomb inventories offer further valuable clues on the regular consumption habits of local elites. ${ }^{79}$ Some types of products are typically found in these tombs, includ-

74 Qianfu lun jian jiaozheng 2.20, trans. Zheng 2008, 97 (with modifications).

75 Ebrey 1980, 335. On steles and memory practices in ancient China, see further Brashier 2011, 2014.

76 See Fabian and Weaverdyck, ch. 3.A, VI.1, this volume.

77 Lewis 2009. See also Leese-Messing, ch. 15, III.3, this volume.

78 See, for instance, an according passage in Hou Hanshu 49.1648, which mentions all of these aspects (among others).

79 The evidence from tomb inventories has a considerable bias toward the Former Han period. This is mainly because the construction style of tombs from the Later Han period, which typically lay directly beneath the surface, had less favorable conditions for the preservation of inventories and especially of organic materials than Former Han tombs, many of which (especially in Hubei, Hunan, Anhui, and Jiangsu) were surrounded by groundwater. 
ing lacquer tableware and cosmetic boxes, jade items, incense burners, and miniature figurines. In some nonroyal tombs, partial body (e.g., face) coverings made out of jade plaques have been found, which speaks of elite emulation processes in mortuary consumption from highest to median elite circles. ${ }^{80}$ The typical finds of exquisite lacquer tableware sets, meant for the deceased to sup upon in the afterlife, indicate the important role of dining and feasting in elite circles. The same is true for the sometimes immense variety of both actually buried and inventoried foodstuffs. The Former Han tombs found at Mawangdui are the most comprehensive and illustrative example in this regard. ${ }^{81}$

To a certain extent, elite consumption of processed food and related elite emulation processes in this field likely promoted artisanal food production. Quite accordingly, transmitted historical texts suggest that one lucrative way of making money as a private entrepreneur was to sell large quantities of processed foodstuffs such as alcoholic beverages, pickles, sauces, and syrups. ${ }^{82}$ Even though future research may bring forth new insights, existing evidence provides little indication that largescale and long-distance import of foodstuffs or spices was involved in local elites' food consumption. ${ }^{83}$

\section{Local Government Institutions}

Local government institutions on commandery (jun 郡) and county (xian 縣) levels were the nodal points connecting commoners and their households with the centralized imperial bureaucracy. The empire-wide network of government agencies and the substantial mobility of officials between them were central to processes such as supraregional elite network building, as well as standardization processes in elite values, tastes, and consumption preferences. ${ }^{84}$ The local institutions were, of course, dependent on the bureaucracy's higher levels in many ways, including the obvious fact that they were compelled to execute imperial laws and directions, and that their leading officials, i.e., commandery governors (shou 守 or taishou 太守) and county magistrates (ling 令), were centrally appointed nonlocals. But the large majority of people employed in the institutions were locally appointed members of the resident population, including part-time employees fulfilling their corvée du-

80 For instance, Xu and Qiu 2014, 48; Shangqiu diqu wenhua ju and Yongcheng xian wenhua guan 1990, 11.

81 Yü 1977 offers many examples of foodstuffs from the Mawangdui finds.

82 E.g., Shiji 129.3274, trans. Watson 1993, 449.

83 For evidence for individual kinds of foodstuffs, spices, as well as food processing methods in ancient China, see Huang 2000.

84 On standardization, see Leese-Messing, ch. 11, V, this volume. 
ties. ${ }^{85}$ On the one hand, the officials in these offices were part of the state's sophisticated system of surveillance and accounting, but on the other, they were strongly dependent on collaboration with local residents, especially local elites. ${ }^{86}$ Of the approximately 130,000 officials in the empire-wide apparatus, about 100,000 are assumed to have been employed in local government agencies. Their wages, paid partly in grain and partly in money, therefore consumed a considerable portion of the state's fiscal revenue. ${ }^{87}$ On the other side of the spectrum, these people brought what might be termed infrastructural state power deep into the lives of people, even though the sheer size of the empire and the ratio between state agents and commoners inevitably set certain limits in this regard. ${ }^{88}$

Local government offices were dealing with a large variety of economic matters including tax collection, land and property evaluation, observance of marketplaces, price regulation, public construction projects, management of conscript, convict, and other forms of labor, and acquisition, storage, transport, and sale of goods, as well as government lending, all of which had enormous practical impact on the local residents' economic activities. Finds of legal texts and administrative documents stemming from local Qin and Han government offices have provided intriguing new evidence for all these aspects. Several of these aspects are dealt with in other chapters of this volume. ${ }^{89}$ One general trend that stands out from the evidence is that the official tasks of local government agencies increasingly involved interactions with private markets. ${ }^{90}$ But apart from the agencies' direct interactions with markets, and their potential to stimulate them, their power also had important, more indirect ramifications on economic processes. Two particularly clear examples thereof are government lending and the related aspect of debt and labor management.

Whereas systematic moneylending does not seem to have been typically involved in the agency's tasks, ${ }^{91}$ local government agencies regularly lent out stored state-owned goods such as grain, tools, carts, and oxen to commoners. ${ }^{92}$ In this

85 On the latter, see Miyake 2013.

86 Xie and Brown 2015.

87 See further Leese-Messing, ch. 11, II, this volume.

88 See, for instance, Su 2010; Korolkov 2016. On infrastructural power, see von Reden, ch. 2, II.2, this volume.

89 For tax collection, see Leese-Messing, ch. 11, II; for construction projects, ch. 11, VI; for observance of marketplaces and price regulation, ch. 15, IV.2, to give just a few examples.

90 Korolkov 2020 provides ample evidence for the rising importance of these interactions in various tasks of local government institutions during the early phase of the imperial period.

91 Transmitted texts do occasionally refer to credits given out, e.g., to sick and widowed people. A more comprehensive approach seems to have been restricted to Wang Mang's reign, when a broadly based system of governmental credits under the control of market officials was introduced. For more details on the lending practices of state institutions, see Leese-Messing, ch. 11, III.4.2, this volume.

92 E.g., Korolkov 2020, 373, with further references. 
regard, state institutions took on a role that in the Roman context, for instance, was typically performed by local elites. In comparison to the latter, the more systematic lending practices by local state agencies are likely to have facilitated access to these goods among the common populace.

But the system of government lending also points toward another important economic aspect of local government institutions, which lay in people's indebtedness to them. The blending of debt and labor management in Qin era local government institutions has been amply demonstrated by Korolkov. ${ }^{93}$ Both commoners and officials could incur debts to government agencies if they were unable to return the lent items or provide compensation for them, and also if they were unable to pay monetary fees or penalties for legal offenses. Yet in both cases debtors could work off their debt by performing labor for the state at the fixed rate of eight coins per day. ${ }^{94}$ Upon the debtors' request, debt labor could be commuted into cash payments rendered in installments, and debtors had the opportunity to hire an adequate substitute to perform the services in their stead. ${ }^{95}$ We know that during Han times the practice of paying a fixed amount of money to local government offices instead of personally performing military service was well established, and there are several indications that a similar option existed with regard to conscript labor duties. ${ }^{96}$ Obviously, the commodification and monetization of labor levies that had been initiated by the practices of Qin institutions was carried forward under the Han.

On a more abstract level, these practices of local government institutions fostered the concept of labor as a quantifiable and tradable commodity. Even though the momentum created by the expansion of private employment itself most likely evolved into the most important factor for labor market development eventually, the wide promotion and consolidation of this mindset by local government institutions is likely to have facilitated the growing wage labor market during the Han period.

93 The following discussion of debt and labor management rests largely on what Korolkov examines in great detail in Korolkov 2021 and Korolkov 2020, esp. ch. 4, sec. 2.4.

94 Shuihudi Qin mu zhujian zhengli xiaozu 1990, 51; Hulsewé 1985, 67-69 (A68). This meant a cost for the state that was four times as high as that for convict laborers, who were provided with a mere subsistence (the daily ration of which was fixed at two coins per day), but lower than that for conscript laborers. Korolkov 2020, 414-415. Obviously, an 'agreement' (yue 約) needed to be entered between the government officials and the debtor to work off the owed amount. Korolkov 2020, 403-404. The concrete labor tasks depended on both local demand and on the debtor's skill. Attested options include minor administrative tasks, construction work, and (extension of) frontier service. In the case of a debtor's change of residence, debts were transferred between different local government offices on the basis of an elaborate accounting system. Korolkov 2020, 376-380. The practice of working off a fine was also sanctioned by Han law. See no. 11 of the "Statutes on Agriculture” (Tian lü 田律) in Barbieri-Low and Yates 2015, 700-701.

95 Shuihudi Qin mu zhujian zhengli xiaozu 1990, 51; Hulsewé 1985, 68.

96 Hsing 2014, 172-175; Korolkov 2021. On the commutation of conscript duties into monetary payments, see also Leese-Messing, ch. 11, III.3. 
Furthermore, the systematic suppression of directly dependent forms of labor by the strong impact that local government institutions exerted on the labor market might be considered a factor for the apparently lesser importance of slavery in early imperial China in comparison to ancient Greece and Rome. In both cases, therefore, the practices of local government institutions had important effects on the labor market, even though via ideological and political rather than economic means. ${ }^{97}$

\section{Primary Producers}

\section{V.1 Agriculturalists}

Like in the literature of other agrarian societies, transmitted texts of early imperial China tend to stress the importance of the farming population (nongmin 農民). High elite writers at court, many of whom were also speaking as members of kinship or regional networks that defined themselves as primarily land based, often refer to farming activities as the 'root occupation' (ben ye 本業), typically declaring them superior to and more worth supporting than the 'branch occupations' of craftsmanship and trade. This ideal of honorable treatment had little to do with a common farmer's reality, however, as most of them were indeed "poor and despised" (pin jian 貧賤) and furthermore “disrespected by local state officials" (li zhi suo bei 吏之所卑), ${ }^{98}$ and ancient writers were very much aware of this fact.

Pre-imperial evidence for private land ownership is scarce, and scholars keep debating exactly when private landownership and trade of land developed. It is clear, however, that by Former Han times, private ownership and alienation of land had evolved into common phenomena. But at the same time, early Han laws still contain regulations regarding land plots of certain sizes to be allocated by the state to both commoners and rank holders. ${ }^{99}$ Independent farmers needed to pay land taxes (mostly grain, but also hay), poll taxes, and corvée dues in the form of military and labor service, as well as property taxes during certain times. ${ }^{100}$ With parts of their taxes having to be paid in monetary form, independent farmers were systematically required to engage in marketing part of their own produce or selling their labor in order to acquire the required amount of cash. According to one estimate, roughly 25 percent of the income of a typical farming household needed to be monetary in order to meet fiscal and other basic expenses. ${ }^{101}$

97 Korolkov 2020, 424-425; Scheidel 2017, 143. See also Leese-Messing, ch. 15, II, this volume.

98 Chao Cuo 昆錯 (ca. 200-154 BCE) as recorded in Hanshu 24A.1133.

99 On property regulations, see Leese-Messing, ch. 11, IV.2, this volume.

100 For more details on the different forms of taxation, see Leese-Messing, ch. 11, II, this volume.

101 Hsu 1980, 79. 
Throughout the early imperial period, millet appears to be the crop produced most. ${ }^{102}$ Nevertheless, cultivation of wheat - which depended more heavily on irrigation but yielded twice as much grain - and barley increased considerably in the northern parts of the empire. The typical repertoire also included hemp, vegetables, and legumes such as soybeans, which increasingly changed from consumption as a staple food to condiments such as bean paste or soy sauce. It appears this kind of processing was a common activity of farming households next to their fieldwork. ${ }^{103}$ For some, they may have been a typical source of monetary income as well. Rice was cultivated in permanent, irrigated fields and in increasing amounts, particularly in the wetter southern regions. Transplantation of rice seedlings was practiced by the second century CE at the latest. Typical cash crops included mulberry, hemp, sesame, indigo, and gourd. Sesame, along with cucumber, watermelons, grapes, garlic and pepper, as well as alfalfa (especially for horse fodder), belonged to a number of new crops introduced via the increasing contacts to Central Asia. ${ }^{104}$ Imperial expansion further increased the variety of landscapes used for agricultural activity. For instance, in the northwestern frontier region including the Hexi corridor and the Tarim Basin, the establishment of 'agricultural garrisons' (tuntian 屯田) involved the reclamation of land in dry regions that had not been used for intensive agricultural production before, and therefore depended on the creation of wide-reaching and investment-heavy irrigation networks. ${ }^{105}$

As a legacy of the Warring States period, early imperial farmers largely engaged in comparably intensive agriculture. A common farming household could likely achieve relatively high yields from rather small plots of land by relying on fertilizers, knowledge about efficient soil and seed preparation, and the proper timing of the steps in agricultural production. Being taxed a fixed amount (instead of a variable one depending on output) may have been an additional incentive for farmers to invest in intensive agricultural techniques that increased the output of their land. Arguably, the widespread use of intensive, high-skill, partly statepromoted cultivation methods was a major reason for the relative scarcity of large estates worked by unfree labor in early imperial China. In comparison to inde-

102 For details on millet production in ancient China, see Bray 1981.

103 The agricultural handbook Monthly Instructions for the Four Classes of People (Simin yueling 四民月令) mentions various processing procedures as typical activities of farming households during certain months. See, for instance, Hsu 1980, 217 (A 11). On the Simin yueling and other ancient manuals, see Leese-Messing, vol. 1, ch. 12.A, 521-524.

104 Hsu 1980, 81-91; von Glahn 2016, 130-132.

105 An analysis of satellite imagery suggests that the irrigation network at the site of Miran/ Milan 米兰 (southeastern corner of the Tarim Basin, in modern Xinjiang) covered an area of more than 2,800 ha, which on estimate would have demanded the moving of over four million sq. $\mathrm{m}$ of earth. Luo et al. 2017; Y. Li et al. 2017, 3. On irrigation systems in the Tarim Basin, see also, for instance, Bertrand 2010. 
pendent farmers and tenants, slaves and servile laborers would have had lesser incentives to increase their productivity either by pure exertion or the acquisition of special skills. ${ }^{106}$

The ideal of a nuclear farming household working their own plot of land, which had developed during the Warring States period, appears to have been implemented to a considerable degree during Qin and early Han times. ${ }^{107}$ Throughout the Han period, however, critics complain about large numbers of formerly independent farmers becoming large landowners' tenants, hired laborers, or slaves. Certain structural factors certainly could have facilitated developments toward larger estates and peasant dependency. In addition to the technological advances that may have advantaged wealthy landowners, common crops like wheat and millet, which were harvested once a year around roughly the same time, were by trend more profitable to richer farming households, who could make themselves independent from the fluctuating seasonal crop prices by investing in storage facilities. Accordingly, hoarding is frequently mentioned in transmitted texts as a serious socioeconomic problem, and some governmental measures targeted hoarding practices among the wealthy. Nevertheless, the real scale of these developments toward large estates and tenancy are hard to fathom, and regional differences, e.g., between different landscapes, climates, and crops, are likely to have played an important role. ${ }^{108}$

The nature of the Han tenancy system is still shrouded in many uncertainties. While transmitted texts mention rents as high as 50 percent (and sometimes more), it is unclear who paid the common state taxes - land and poll tax plus corvée duties - or if they were paid at all. Some scholars suggest that tenants were removed from the state registers and thus did not pay taxes. Others suggest that the landlord was expected to pay the taxes for each tenant, even though this obligation could at times be illegally bypassed with the connivance of local authorities. It has also been argued that tenants payed some of the taxes, especially their corvée dues, themselves. ${ }^{109}$ Different practices are again likely to have been prevalent in different regions, so that any explanations of the advantages of the tenancy system remain problematic. It should be noted, however, that even the largest estates of the Han period seem to have been much smaller than the latifundia of the Roman Empire. ${ }^{110}$

106 Lewis 2015a, 284-285; Hsu 1980, 3-15, 57, 33-66, 91-128; Wilbur 1943, 215-216.

107 On households, see further sec. VI below.

108 Hsu 1980 (65-66) suggests that the proportion of tenants among the total population at the time of Emperor $\mathrm{Wu}$ was in the range of 4 to 20 percent. On evidence for tenancy during the Former Han and Wang Mang periods, Wilbur 1943, 210-215; see further Leese-Messing, ch. 15, I.2, this volume.

109 For examples of such differing assumptions, see Lewis 2007, 111; Bielenstein 1979, 148-149; Hsu 1980, 54; 16, respectively.

110 Lewis 2007, 115, 2006, 218 with n. 218, and 225. 


\section{V.2 Pastoralists and Animal Economies}

The supposed contrast and allegedly clear division between 'interior' settled farmers and 'exterior' mobile pastoralists is a topos in ancient elite discourse. Pastoralists were typically - and often disrespectfully - associated with northern and northwestern 'barbarians' that the Han referred to as Xiongnu and Qiang 㒸. The contrast gained currency among proponents of Han expansion toward regions that facilitated pastoralist economic strategies. ${ }^{111}$ The dividing lines between agricultural and pastoral lifestyles and regions in the early Han Empire's north, northwest, and beyond seems to have been less clear-cut than some simplistic phrasings in transmitted sources suggest. The Qiang people that ancient Chinese texts mention in the context of several areas of the empire's northwest, for instance, seem to have practiced a mixed economy combining animal husbandry, agriculture, and fishing. ${ }^{112}$ The idea that the Han Empire's pastoralist neighbors and frontier inhabitants were dependent on Chinese agricultural products has also been called into question. ${ }^{113}$

It is not easy to fathom the scale and forms of animal husbandry in the interior regions of the Han Empire that largely relied on cereal agriculture. It is commonly assumed that in the early Chinese empires, pasture lands were not extensively integrated into the rural economy. ${ }^{114}$ Especially for the densely populated lowland regions characterized by intensive agriculture and scarcity of land, this assumption is certainly not far-fetched. With regard to animal husbandry, texts regularly mention chickens, pigs, sheep/goats, dogs, horses, and cattle/oxen (especially as draft animals). The most typical case seems to have been small-scale rearing of chickens and pigs as a supplementary occupation of farming households. Pigs were especially important as providers of manure, and, according to an agricultural handbook, were to be slaughtered only once a year. ${ }^{115}$

Transmitted texts provide clear evidence for large-scale, specialized, and commercial breeding of sheep/goat, pigs, cattle, and horses, all of which Sima Qian 司馬遷 (145 or 135-ca. 87 BCE) acknowledges as reliable sources of considerable income. ${ }^{116}$ Herding is also often mentioned in the context of providing jobs for poor people and minors. ${ }^{117}$ Outer frontier zones apart, our sources are likely to underrepresent various forms of pastoralism and animal economies, for instance in moun-

111 Different views toward imperial expansion often went along with different assessment of pastoralists, as exemplified by the different views expressed by the two historians Sima Qian and Ban Gu. See Chin 2010.

112 See further Weaverdyck et al., ch. 7, VI, 321-327, this volume.

113 Di Cosmo 1994.

114 Bray 1979, 3.

115 Hsu 1980, 131-132; Yü 1977, 74-75.

116 Shiji 129.3260; 3272; 3280, trans. Watson 1993, 440, 448, 452; Shiji 30.1431, trans. Watson 1993, 73.

117 Hsu 1980, 132, 312-314. 
tainous regions. They may have been less integrated into the administrative and fiscal system, which by tradition was based on cereal-producing farming households. The economic implications of pastoralism, both on the frontiers and in the inner parts of the empire, are in need of further research. ${ }^{118}$

\section{Households}

\section{VI.1 Household Registration and Household Composition}

The household ( $h u$ 戶) served as the main unit for taxation and conscription of military and labor service for the early imperial state. Its system of civil registration included records of household members, their age and gender, their landed property, productive assets, dwellings, gardens, and tax obligations, privileged exemptions, and infirmities, as well as inheritances and other transfers of property. By making its population and resources 'legible' through household registers, the state possessed the capacity to exercise control over this basic economic unit to a degree and on a geographic scale that stands out among ancient societies. ${ }^{119}$

The concept of the household had evolved during the Warring States period when several competing states tried to intensify control over their economic and human resources, which implied an attempt to maximize the acreage under cultivation. Accordingly, the 'ideal' household - from an imperial state perspective - consisted of a slightly extended nuclear family independently cultivating a plot of land according to their members' labor capacity. These would normally include husband, wife, children, and the husband's mother, if still alive. Transmitted and excavated household data from the Qin and Han periods suggest that typical households consisted of nuclear families that sometimes extended to include elderly parents or unmarried siblings, as well as sometimes slaves and servants. ${ }^{120}$ On average, however, realities do not seem to have deviated too much from the ideals, and households comprising around five people do seem to be the norm. ${ }^{121}$ As for urban house-

118 I shall discuss other producers in sec. VIII below.

119 Von Glahn 2020, 11-12.

120 While some excavated Qin household data do incorporate slaves, this is not clear with regard to many other reported household figures. In excavated Han documents from Juyan, for instance, slaves are listed in property (rather than household) registers. Often, therefore, some uncertainty remains with regard to both composition and size of the reported households. For the question of slaves as household members, see Yates 2014, 215; Hsing 2014, 164-165. Further uncertainties exist, for instance with regard to the registration of local residents in frontier zones. See, e.g., W. Wang 2014.

121 No individual household registers from the Han period have been published yet. Barbieri-Low and Yates 2015, 785. For some examples of excavated Han summary reports, see Hsing 2014. The figures suggested by excavated summary reports and by the "Treatise on Geography" in the Hanshu (each giving numbers of inhabitants and of households) are pretty compatible. For instance, exca- 
holds, figures from the Former Han capital Chang'an suggest that they tended to be smaller than common rural households. ${ }^{122}$

\section{VI.2 Consumption and Distribution}

Estimates based on transmitted figures of empire-wide totals of cultivated land and people suggest that the farm of an average household in 2 CE would have measured $78.7 \mathrm{mu}$ of land (i.e., about $3.63 \mathrm{ha}$ ), which in normal years would likely produce grain yields sufficient to cover subsistence costs for its approximately five members and obligatory in-kind tax payments. ${ }^{123}$ But as has been mentioned, the monetary share of taxes systematically required households to produce a certain surplus (e.g., additional grain, cash crops, or textiles beyond subsistence needs) and engage in market transactions. This aspect is even clearer in the case of moderately well-todo farming households, for whom both the regular selling and buying of certain goods - ranging from agricultural crops to textiles - appear to have been routine activities. $^{124}$

The state was interested in keeping as many tax-paying households on its registers as possible. Legal regulations, therefore, offered a good deal of flexibility with regard to inheritance. Making a legally binding will for the division of a householder's possession was possible, conceivably without restrictions regarding primogeniture or gender. ${ }^{125}$ The same state concern is further reflected in inheritance regulations that provided for slaves to become householders, either after manumission or after their masters' death without heir. ${ }^{126}$ In the model household, the husband would take over the role of 'householder' ( $h u$ ren 戶人). Under the state's allocation scheme still covered by early Han legal regulations, the eldest son would inherit the father's status upon his death, along with his land, or parts of it, if the father

vated household register summaries for Dongyang county (in modern Anhui Province) suggest an average household size of 4.46 persons, while the Hanshu figures for the superordinate commandery of Linhuai suggest 4.61 persons per household. See Hsing 2014, 172. For the figures for the county of Yinwan 尹灣 and its superordinate commandery of Donghai 東海, see Loewe 2004, 60.

122 For instance, Hanshu 28 (1543, 1545, and 1547) suggests the average ratio of households to persons to have been 1:3 in Chang'an and its surrounding area, 1:3.5 in Changling, and 4.5 in Maoling. See also Nylan 2015, 26; Loewe 2015, 213.

123 Bielenstein 1979, 147-148. Probably depending on time period regional variety, plots could also be much smaller, as suggested by some excavated household data. See, e.g., Lewis 2006, 90-91.

124 This is demonstrated most clearly by the transmitted fragments of Han-era agricultural handbooks, on which see Leese-Messing, vol. 1, ch. 12.A, IV.

125 The Han statute does not refer to any such restrictions. Barbieri-Low and Yates 2015, 800-801 (latter part of no. 17, slips 333-336). Tang administrative forms for the declaration of wills include places explicitly left for various classes of relatives, including younger sons and daughters. Barbieri-Low 2011b, 143.

126 Barbieri-Low 2017; Yates 2014, 215-216. 
had a higher rank than his son. Younger brothers would have been eligible to form their own households on pieces of land according to their official rank, which could - depending on rank and number of brothers - also involve the allocation of additional land. Population growth and the resulting scarcity of land in populous regions must have put this system under pressure early on, and it was increasingly replaced by a system of alienable land and private ownership. ${ }^{127}$ Consequently, many estates would have to be broken up over time, and eventually 'supernumerary' descendants of independent farmers would have had to migrate to less densely populated areas, sell their labor as hired workers, or become tenants.

Patrilineal orientation of families was likely not as strong during Han times as has often been claimed. From excavated legal texts from the early Han period, it is clear that women who were not “somebody's wife” (ren qi zhe 人妻者) could become householders when no male heir existed. As such, they would also inherit the former householder's (i.e., their father's, husband's, or son's) honorific rank and possessions. A female householder who eventually got married was entitled to take back her former possessions and land in case of divorce or her husband's death. ${ }^{128}$ Even though the large majority of householders were male, households led by women appear to have been a common phenomenon rather than a rare exception. ${ }^{129}$ This may have been particularly true for times of frequent warfare, when many male householders died in battle. ${ }^{130}$ Furthermore, there is evidence for cases of uxorilocal marriage and of widows returning to their natal family along with their children rather than living with their deceased husband's parents. Widow remarriage was yet another common phenomenon. The passionate discouragement of this practice in elite texts is best understood as a reaction to its ubiquity and the fear that widows diminished the wealth of the patrilineal household by taking back their dowries. ${ }^{131}$

\section{VI.3 Households and Labor Organization}

\section{VI.3.1 Labor Division along the Lines of Age and Gender}

Some excavated documents of household registration include information on how many household members were regarded as 'capable of engaging in field work'

127 See M. Gao 2003 and the early Han "Statutes on Households” (Hu lü 戶律) with the according subsumptions by the translators in Barbieri-Low and Yates 2015, 783-822. For inheritance regulations in early Han law, see, for instance, X. Liu 2007.

128 Barbieri-Low and Yates 2015, 860-881 (no. 13 of the "Statutes on Establishment of Heirs"); K. Gao 2008, 89.

129 A Qin board found at Liye listing numbers of households of various ranks, including households led by adult women, which probably made up 3 out of the 25 listed households (i.e., 12 percent). Yates 2014, 216. See also Nylan 2010, 269, 271.

130 K. Gao 2008.

131 Hinsch 1998. On the relative importance of dowries during Han times in comparison to later times, see Hinsch 2011, 65. 
(neng tian 能田). In the documents from Fenghuangshan 鳳凰山, in which the average size of a household is 4.6 people, the majority of households are reported to have had either three or four people in this category. This suggests that women as well as elderly and minors were counted as standard contributors to the households' agricultural labor. ${ }^{132}$ Furthermore, elderly and minors that were no longer or not yet physically capable of heavy work could still be effectively used for lighter but indispensable tasks such as infant care or animal keeping.

A widespread and oft-cited ancient Chinese paradigm of gendered labor division in agricultural households was that of the farming man and the mulberryplucking, spinning, and weaving woman. Both transmitted and archaeological evidence suggest, however, that the ideal of strict gendered labor division was, above all, an elitist expression of wishful thinking that was thwarted by the majority of people's social and economic realities. While many women in farming households likely engaged in textile production, it is clear that most of them would mainly have worked in the fields alongside the male household members, at least during the seasons of intensive agricultural work. ${ }^{133}$ Even in some of the idealized models of gendered labor division, women's engagement in domestic textile production appears to have been seen as a vespertine addition to their daytime work. The historian Ban $\mathrm{Gu}$, for instance, envisioned "female labor of one month" to be "equivalent to forty-five days," counting each evening spent on textile production as an extra half of a productive working day. ${ }^{134}$ The seasonality of agricultural work in particular left excess labor time for spinning and weaving during the winter season. Estimates based on transmitted reports on average productivity, subsistence consumption, and price levels suggest that a household's textile production could easily compete with that of food crops, and bore considerable potential for creating a marketable surplus. ${ }^{135}$

Because older children were also important contributors of labor within households, education rarely went beyond learning from and adopting the parents' routine work, and thus gave little opportunity for social mobility. For households who had acquired moderate or even great wealth, however, children's literacy, as well as training in legal and scholarly texts during agricultural slack seasons, or even beyond them, seems to have been an important and promising investment, as it provided a chance for careers in the bureaucracy and therefore social mobility. Education of a household's (mostly male) offspring could be provided either by household or other family members, private teachers, in state-run scribal schools, ${ }^{136}$ or in

132 Lewis 2006, 91.

133 Hinsch 2011, 67-78; Nylan 2010, 280-282.

134 Hanshu 24A.1121, trans. Hsu 1980, 310; Swann 1950, 129.

135 Hsu 1980, 79; 130-131.

136 The scribal profession was originally hereditary, but was opened during the beginning phase of the imperial era to members of non-scribal families, who could enter local government agencies 
occasionally mentioned local schools, which, however, do not seem to have been of great importance. ${ }^{137}$ If promising children were born into relatively poor households, kinship ties between households of unequal wealth would have been essential to their educational prospects. ${ }^{138}$ However, even for families with a scholarly background or history of officeholding, losing a child's manpower for the sake of its education could be a serious challenge during times of economic or political turmoil. This indicates that for most households these investments, which may further have involved tuition fees, must have been beyond reach. ${ }^{139}$

\section{VI.3.2 Slaves in Private Households}

Male and female slaves ( $n u$ 奴 and $b i$ 婢 $)^{140}$ frequently contributed labor to Qin and Han households, though this was not standard practice. ${ }^{141}$ The households in the excavated Qin registers mentioned above had at most one slave each, while some Han property registers mention several slaves. ${ }^{142}$ But transmitted texts suggest that wealthy households easily contained tens and hundreds of domestic slaves. Individual owners are even associated with thousands and ten thousand slaves, even though exaggeration may be at play in many hostile remarks. ${ }^{143}$ The proportion of slaves among the overall population is difficult to estimate but is commonly assumed to have been considerably lower than in the Roman Empire. ${ }^{144}$

as so-called scribal 'assistants' (zuo 佐). The according education of the latter, however, apparently did not start before adulthood. Ma 2017.

137 Ch'ü 1972, 29-30; Bielenstein 1979, 184-185. Education of minor household members (in this case, in schools) during agricultural slack seasons is also mentioned in the agricultural handbook Simin yueling. See Hsu 1980, 216, 224.

138 For some examples of support for education among family members within and beyond households, see Ch'ü 1972, 27-29. For other economic functions of kinship networks, see further LeeseMessing, ch. 15, IV.3, this volume.

139 See, for instance, the example of the Sunshu family in Ebrey 1986, 627-628, as well as 635637.

140 These are the terms used by Han laws, which seem to have changed or refined the legal nomenclature of slaves that had been used during Qin times. See Yates 2014, 212, 221-222.

141 Apart from privately owned slaves, there were also government slaves. See Wilbur 1943, 221236; Yates 2014, 211-212.

142 For instance, see the example from Juyan given in Loewe 1967, 1:72.

143 Under Emperor Ai (r. 7-1 BCE), high statesmen proposed to legally limit slave holdings of all kinds of nobles, honorific rank-holders, and commoners, with the highest limit being 200 slaves for kings, and the lowest being 30 slaves for commoners. This suggests that actual numbers must often have been considerably higher. Neither was the proposal put into effect. See Hanshu 24A.1142, trans. Wilbur 1943, 435-437. For references to higher numbers, see Wilbur 1943, 170; Ch'ü 1972, 146-148.

144 Scheidel 2017, 137-138. 
After the discovery of legal texts, our knowledge about the social role and legal status of slaves has increased considerably during recent decades, but surprisingly little is known about the specific activities of private slaves. Occasional references in transmitted texts do associate them with a large variety of tasks, including domestic services, accounting, manufacturing, farming, herding, bodyguarding, tomb-guarding, escorting, courier service, entertainment, sexual services, financial management, and trading. ${ }^{145}$ But the texts do not suggest which occupation was the most common. Evidence for private slaves being engaged in agriculture does exist, and finds of tomb figurines identified as agricultural slaves suggest that they may have been more common than had been assumed in earlier scholarship on the topic. ${ }^{146}$ But on the whole, the evidence is still relatively scarce and largely presumptive. A demographically induced abundance of free agricultural labor coupled with the widespread concept of labor time as a quantifiable commodity and a corresponding awareness of the expensiveness of slack time may have contributed to the relative unattractiveness of slavery in agricultural contexts. ${ }^{147}$ There is some evidence for slaves being used as their masters' agents in both small-scale and large-scale mercantile activities. ${ }^{148}$ Nevertheless, it is again hard to say how important slavery was in relation to paid agents who are associated with similar tasks. Furthermore, it is obvious that the possession of slaves was not only regarded as a productive economic resource but also - and maybe even primarily - a wealth-consuming manifestation of status. ${ }^{149}$

145 Wilbur 1943, 178-220; Ch'ü 1972, 146-151.

146 For the classic standpoint, see Wilbur 1943, 195-216, with the main conclusion being that slave labor was "relatively unimportant" in agricultural production, and that "an important proportion of all slaves was employed most of the time in nonproductive activities” (216-217). Cf. Scheidel 2017, 138-142, who thinks it "legitimate to consider a more expansive scenario of agrarian slavery, where 100,000 s of slaves might have worked the fields and tended livestock" (141). For summaries of the evidence from finds of figurines which, according to the inventory lists, represented private agricultural slaves at Fenghuangshan, see Barbieri-Low 2007, 252-253; von Glahn 2016, 111-112.

147 On the concept of labor (time) as a quantifiable commodity, see sec. IV above and LeeseMessing, ch. 11, II.2, this volume.

148 A famous mock slave contract listing all conceivable types of slave labor, for instance, contains a rather lengthy passage describing the slave's duties in the trading business. These duties include both petty peddling activities and businesses requiring extensive travel, and further comprise both merchandizing the households' own produce and retailing external craft products. Slaves could also be used for types of labor that required a considerable amount of skill and autonomy. There is frequent mention of 'supervising slaves' (jian $n u$ 監奴), which might indicate a ranking within a household's slave labor force. The historian Sima Qian also gives the example of a successful entrepreneur who chose his slaves according to their cleverness in order to make profitable use of them in trading activities, while enabling the best of them to considerably enrich themselves. Sima Qian also says, however, that other than Diao Xian, many people would rather regard a slave's cleverness as something worrisome, suggesting that the way Diao Xian made use of slaves was not a standard behavior.

149 Wilbur 1943, 195; Scheidel 2017, 140. It is very clear that slaves also functioned as a status symbol. For instance, slaves of wealthy households are frequently depicted as wearing fancy silk 


\section{Traders}

\section{VII.1 Designated Merchants and other Traders}

The most common ancient Chinese terms for 'merchants' are shang 商 (or shangren 商人), gu 賈 (or guren 賈人), or the composite, shanggu 商賈. The terms could be used both for large-scale, highly mobile merchants as well as for small-scale peddlers or market stall keepers, with shang showing a tendency toward the former and gu toward the latter. ${ }^{150}$ Several other, slightly more specific terms also appear in texts, such as 'marketeers' (shiren 市人), which typically referred to traders renting official marketplace stalls. Texts also mention people engaged in 'peddling' ( fan 販), a term that appears to have been used especially for relatively small-scale commercial activities that were legally tolerated without registration in a market register up to a certain time period. ${ }^{151}$ Beyond the clear case of market stall renters, the exact conditions under which merchants or other sorts of trading actors required registration and were subject to corresponding legal regulations and taxes are not yet fully understood. At least for a modern reader, the seeming absence of clear-cut distinctions creates some ambiguity in the interpretation of many ancient passages, as these do not always leave a clue about what kind of trading actors exactly a certain depiction, accusation, or legal measure applied to.

Not only those actually designated as 'merchants' were involved in trading activities. The aforementioned terms mostly refer to people that specialized in buying and selling other people's products. Both small and large landowners, some of whom would certainly qualify as 'businessmen' in the modern sense with regard to their substantial mercantile activity, were therefore not commonly implied when people spoke of 'merchants.' 152 In practice, then, the boundaries between traders

dresses and eating good food, and making one's slaves wear coarse clothes could be interpreted as a sign of modesty. Wilbur 1943, 186.

150 A Later Han commentator (i.e., Zheng Xuan 鄭玄, 127-200 CE), referencing the Zhouli 周禮, suggested that "mobile [traders] were called shang, and settled [traders] were called gu" 行曰商, 處曰賈 (Shiji 85.2505), but the two terms' usage in Han texts does not suggest such a clear distinction. That Zheng Xuan felt the need to explain their difference as a contemporary only purports this impression. By trend, shang appears to have implied large-scale trading activities more typically than gu did, but in this regard, too, no clear distinction is perceivable. There are, for example, also references to 'wealthy gu' ( $f u$ gu 富賈) and 'big gu' ( $d a$ gu 大賈), and to both 'the big' and 'the petty' among the shanggu (e.g., Hanshu 24A.1132).

151 S. Chen 2015, 109 (slips 124-126); Korolkov 2020, 570-571.

152 Cf. Ch'ü 1972, 113, who argues that 'the term 'merchant' ... also included persons engaged in mining (particularly iron and cinnabar), salt manufacturing, cattle and pig breeding, raising fish, manufacturing, and moneylending." He does not mention the Chinese term for 'merchants' he is referring to. As a reference, he gives the whole chapters of Shiji 129 and Hanshu 91, which are, however, not entitled "merchants" (shanggu), but "those whose goods increased" (huo zhi 貨殖), which is a much more general term coming close to the meaning of 'businesspeople,' under which the historians further also counted mercantilist landowners. 
and landowners must have been fuzzy, also because merchants tended to invest heavily in land. On a more general note, it would be wrong to assume that all trading activities - or even all those that involved reselling other people's produce were undertaken by people who were actually termed 'merchants.' Landowners, artisans, local officials, envoys, and dependent laborers certainly played substantial roles in the trade and movement of goods without being designated 'merchants.'

Despite certain legal restrictions that applied at least during certain phases (on which see below), the option of becoming an actual 'merchant' was not strictly limited to specific social groups. This is quite clearly suggested by prognostic texts that offer a great variety of future 'career paths' for newborns that depended on their date of birth, but not on the occupational group that they were born into. To give just one telling example, a prognostic text from the Qin period also considers female infants as potential future merchants, predicting that "if one gives birth on a gengyin day: if a girl, she will become a merchant” 庚寅生子, 女為賈 $(g u) .{ }^{153}$ Women are, in fact, mentioned quite frequently with regard to trading activities in early imperial texts. ${ }^{154}$ More generally, becoming a merchant was clearly an alternative path to subsistence and success for the otherwise socioeconomically marginalized. Sima Qian expressed this very clearly when he stated that engaging oneself as a "merchant" (shang) was the very best means to "work one's way up from poverty to riches” (yong qiong qiu fu 用貧求富). ${ }^{155}$

The means through which ancient Chinese merchants managed their work concretely, especially with regard to risks in large-scale and long-distance trading operations, are a difficult scholarly issue. Occasionally, texts refer to larger groups of merchants traveling together. For instance, a historical account mentions a caravan of merchants traveling near the northern frontier (in today's Inner Mongolia), which reportedly consisted of over a thousand ox-drawn carriages. ${ }^{156}$ Merchants' means of collaboration are, however, largely unclear. For instance, there is no evidence for the existence of guilds in early imperial times, though eventually they became important organizations from the Tang period onward. ${ }^{157}$ Neither do our sources indicate the existence of anything that would come close to the 'voluntary associations' of the Graeco-Roman world in which traders banded together with each other or with other economic actors on the grounds of their shared profession or shared

153 Shuihudi Qin mu zhujian zhengli xiaozu 1990, 203; Barbieri-Low 2007, 58.

154 Hinsch 2011, 77-78.

155 Shiji 129.3274, trans. Watson 1993, 449 (with modifications).

156 Hou Hanshu 90.2983. Assumedly, the caravan merchants, whom the passage reports to have been raided by Wuhuan 烏桓 people, were themselves residents of Han territory, even though it cannot be ruled out that they were merchants from a foreign country. Yü Ying-shih refers to them as a "Chinese caravan.” Yü 1967, 108.

157 On this issue, see further sec. VIII.1 below. 
range of traded goods. ${ }^{158}$ Furthermore, except for artisans who traded their own products in city market stalls (see sec. VIII below), little is known about the relationships and means of cooperation between traders and producers. With the apparent absence of formal private organizations, merchants' arrangements for collective timing, financing, and risk management are likely to have involved higher transaction costs, as they must have rested largely on more informal and partly more inflexible interpersonal relationships based on kinship and extended private networks. ${ }^{159}$

There is some scarce evidence for foreign merchants being active not only in frontier regions and designated 'border markets' (guanshi 關市), but also in more central regions of the empire. Wang Zijin has dedicated a whole article to what he calls an “internationalization” (guojihua 国际化) of the market (and marketplaces) in and around the Later Han capital Luoyang. ${ }^{160}$ But in fact, next to references to foreign diplomatic missions to the court that involved the exchange of goods, ${ }^{161}$ only very few of his collected passages indeed can be considered as evidence for the presence of foreign traders. One anecdote mentions a group of "Hu merchants from the Western Regions” (Xiyu gu Hu 西域賈胡) being executed for unwittingly breaking a restriction by killing a powerful official's rabbit outside the city walls, but it does not give any further detail about their mercantile activities or the general circumstances of their stay. Another passage, albeit referring to the third century CE, speaks of the region around Luoyang attracting all kinds of people in their striving for profit, among them "Hu and Mo (i.e., various northern foreign) merchants" 商賈胡腼. ${ }^{162}$ On the basis of such scattered references, one is left to speculate on the broader relevance of foreign traders in the Han Empire's central regions and on their potential role in border-crossing trade networks in particular. In this regard, it is worth remembering the first-century CE case of the historian Ban Gu mentioned in section II.1 above. When he felt like procuring exquisite Central Asian products, he did not consult either Han or foreign merchants at Luoyang, but rather placed the order with his far-travelling brother.

\section{VII.2 Attitudes toward Merchants and their Official Treatment}

Disdain for merchants in ancient China is a common topos in Sinological scholarship. And indeed, transmitted Han sources are full of people's criticism against mer-

158 See Fabian and Weaverdyck, ch. 3.A, IX.1.2, this volume. However, the fact that our available sources are largely silent on merchants' organization practices does not mean that they did not exist.

159 On this issue, see further Leese-Messing, ch. 15, IV.3, this volume.

160 Z. Wang 2018.

161 On the role of foreign delegations, see sec. $\mathrm{X}$ below.

162 Hou Hanshu 34.1182 (memoirs section); Sanguo zhi 21.624 (commentary no. 1), both quoted in Z. Wang 2018, 18. 
chants, scorning them for acting selfishly, hoarding goods, fleecing people, breaking sumptuary rules, engaging in criminal activities, and causing a lack of labor capacity in the 'root occupation' (ben ye 本業) of farming. ${ }^{163}$ In addition to their trading of goods, merchants frequently get associated with moneylending for interest - an activity that was sneered at even more vigorously than trading goods in general. Reportedly, members of middling families acted as their "guarantors" and “serve[d] them as diligently as if being their subjects and servants” 為之保役, 趨走與臣僕等勤, while even ennobled people "bowed their heads in their dependence” 低首仰給 on the wealthy merchants. ${ }^{164}$ The economic power of merchants, therefore, was considered a threat to hierarchical social norms among certain layers of society.

In this respect, the seemingly unambiguous picture of the 'dishonorable merchant' needs to be clarified. First of all, the sources in which we find such disdain are strongly biased toward opinions expressed by the highest members of the elite. Their critical stance is not surprising since wealthy merchants could easily evolve into a threat to central state power and to those groups of local elites whose social standing was based on a more traditional foundation, such as landholding, official titles, and honorific ranks, as well as observance of ritual codes and sumptuary rules. It has been suggested that harsh antimercantile sentiments evolved into a common view only from the early Han period onward, when the growing commercialization of the land market enabled an expanding merchant class to accumulate private land. 165

Members of lower social strata, who actually dealt with different types of merchants in their daily lives, likely took a different view than what is reflected in the available evidence. The deviation of social reality from the ideal of the lowly merchants was also seen by members of the highest elites themselves. The high statesman and political advisor Chao Cuo 昆錯 (ca. 200-154 BCE) complained that "even though legal statutes despise merchants, they have become rich and cherished ... So those that are cherished among the common people are those that the ruler despises” 今法律賤商人, 商人已富貴矣 [...]; 故俗之所貴, 主之所賤也. ${ }^{166}$ And even the standpoints toward merchants expressed by high elite members do reveal quite a variety on closer inspection. Whereas the historian Sima Qian's promotion of wealthy entrepreneurs as promising candidates for replacing the old hereditary aris-

163 The latter is a frequent point of criticism against merchants, but one may wonder if it was based on a real problem. Hsu 1980, 39, suggests that a looming food shortage during the midsecond century BCE, which was "in all likelihood related to the increase in population" was "misunderstood ... and attributed to the outflow of the farming population to commerce." For a classic case of Han-era criticism in this regard, see Chao Cuo's famous 178 BCE memorial quoted in Hanshu 24A.1130-34, trans. Swann 1950, 158-169; Hsu 1980, 160-163.

164 Hou Hanshu 28A.958, trans. Hsu 1980, 196-197; Shiji 30.1425, trans. Watson 1993, 68.

165 Sterckx 2015, esp. 212, 242.

166 Hanshu 24A.1133, trans. Hsu 1980, 162; Swann 1950, 166 (with modifications). 
tocracy may have constituted a rather rare position, ${ }^{167}$ we know of other people voicing positive attitudes regarding the role of merchants in society. They stress the indispensability of traders for moving goods where they are needed, and a decrease in merchants gets associated with an undesirable rise in prices. ${ }^{168}$ They also point out that the livelihood of certain primary producers, especially people living in natural surroundings of lesser or no agricultural suitability, such as mountain dwellers, essentially depended on mobile traders buying and reselling their products. ${ }^{169}$

The relationship between merchants and the state, too, was not constant or unambiguous. Evidence for the Qin period indicates that during the early years of the imperial period, merchants were indeed legally segregated from other social groups. Marriage between merchants and members of other groups was punishable, and merchants were counted as one of several underprivileged groups that were mobilized for certain military endeavors. ${ }^{170}$ The latter practice is also known to have been applied in the case of some military undertakings under Emperor Wu of Han. ${ }^{171}$ Furthermore, one of the early Han legal statutes on labor service designates "unrespectful marketeers” (shiren bu jing zhe 市人不敬者) for tasks involving heavy labor (i.e., the repair of walls, roads, and bridges belonging to marketplaces). ${ }^{172}$ The founding emperor of the Han introduced sumptuary restrictions for merchants, forbidding them from wearing silk robes and riding in carriages. However, these restrictions were given up under his successors. ${ }^{173}$ At least during certain phases, and possibly for the major part of the Han era, merchants and their descendants were officially excluded from office holding, which restricted the opportunities of turning economic power into political power to a certain extent. The rule was, however, either not continuously enforced or not consistently followed. A few members of merchant families even achieved higher official posts. Sang Hongyang 桑弘羊 (ca. 152-80 BCE), Emperor Wu's central economic policy maker and son of a merchant, is the most prominent example. He had been promoted because of his calculation abilities and eventually gained one of the three highest government posts. ${ }^{174}$ But even in the case of merchants' exclusion from office holding, their ability to transform economic into political power was by no means eliminated. With regard to the relationship between merchants and state functionaries alongside or in defiance of the latter's official tasks, transmitted texts provide ample indications of frequent collaboration between merchants and

167 See Leese-Messing, vol. 1, ch. 12.A, II.3.

168 In Shiji 30.1440 (trans. Watson 1993, 81), Sima Qian paraphrases Bu Shi's 卜式 understanding of contemporary economic developments as follows: "because of the tax on boats, traders had diminished in number and the price of goods gone up” 船有算, 商者少, 物貴.

169 Yantie lun jiaozhu 3.43, trans. Gale 1967, 23.

170 W. Chen 2012, vol. 1, 161 (tablet 8-466); Shiji 6.253. See also Korolkov 2020, 601.

171 E.g., Shiji 113.2974-2975; 115.2987, trans. Watson 1993, 215-216, 226.

172 Barbieri-Low and Yates 2015, 902-3 (no. 4 of the "Statutes on Government Service," slip 414).

173 Shiji 30.1418, trans. Watson 1993, 61.

174 Shiji 30.1418, trans. Watson 1993, 62; Ch'ü 1972, 118-122. 
state functionaries at different levels of the bureaucracy. In one case, a central official was even accused of having given confidential information on planned government measures to a merchant, to which the latter could then attune his economic decisions by hoarding certain goods. ${ }^{175}$ Even more so, underhanded dealings between local officials and merchant acquaintances are likely to have been the rule rather than the exception.

It was also under Emperor Wu's reign that a couple of rigid measures were introduced that ran counter to merchants' interest. Among others, he restricted the ownership of land by registered merchants and increased their taxes, including special taxes on merchants' possessions and their vehicles. ${ }^{176}$ Apart from the information we get on such momentary changes in taxing policies, it is often hard to tell which merchants were taxed, which rates they paid, and how their taxes were collected, especially if they were not operating from official market stalls. For instance, we also hear of complaints such as the one of the statesman Gong Yu 貢禹 (12444 BCE) from the year 44 BCE, in which he bemoaned that merchants (shanggu 商賈), even though collecting yearly profits of 20 percent, were not paying any taxes at all. ${ }^{177}$ During the Later Han period, under Emperor Ming 明 (r. 57-75 CE), there was an attempt to prohibit people from combining mercantile and agricultural activities, but it does not seem to have been seriously enforced. ${ }^{178}$

In general, both the evidence of pragmatic and illicit cooperation between merchants and officials and the ongoing references to powerful merchants certainly show that neither common sentiments nor short- or long-term state policies effectively suppressed them. It is to be assumed, however, that the combination and mutual reinforcement of both did create a noticeable dampening effect on the overall vigor of mercantile activity during the early imperial era.

\section{Craft Producers}

\section{VIII.1 Craftspeople and their Social Status}

The word used in ancient China for various types of craftspeople and artisans is gong 工. ${ }^{179}$ We also find it in all kinds of compound expressions, such as shigong

175 The latter example refers to a case in which the accusations eventually turned out to be partially false, but it nevertheless indicates a plausible scenario, variants of which are highly likely to have happened frequently. Ch'ü 1972, 183-184.

176 Shiji 30.1430; 1440, trans. Watson 1993, 72, 81.

177 Hanshu 72.3075, trans. Hsu 1980, 167.

178 Ebrey 1986, 615.

179 Etymologically, the character (already appearing on Shang oracle-bone inscriptions) is most probably a simple pictographic logogram for a tool, possibly a carpenter's square. Barbieri-Low 2007, 32-36. 
石工 ('mason,' 'stone carver'), ${ }^{180}$ xigong 舄工 ('shoemaker'), or huangtu gong 黃塗工 ('amalgam-gilder'). In transmitted texts, handicraft professions are often treated as dishonorable, but disdain against them was less pronounced than in the case of merchants. The reason for this was certainly that craftspeople were less likely to become threateningly rich. Literary and epigraphic evidence suggests that most of them maintained little more than a subsistence-level standard of living, and that wealthy craftspeople were rather exceptional. ${ }^{181}$ Whereas there is some evidence for caste-bound artisans both in much earlier times and in the post-Han period, this was obviously not the case in the early imperial period. Qin and Han artisans could enter officialdom and even rise to high administrative posts. ${ }^{182}$ After trading, engagement in craft production was, according to Sima Qian, the second best opportunity for poor people to climb up the socioeconomic ladder. ${ }^{183}$

A legal statute from the Han period indicates that the state identified craftspeople separately for specialized labor service in state workshops (see below). The statute states that all other members of the household were exempted from conscript duties and probably the poll tax for the period that one member was serving as an artisan. Since the text mentions probationary periods of two years, it is to be assumed that these artisans usually worked in the workshops for lengthy periods, possibly working one month per year as unpaid conscripts ${ }^{184}$ and the rest of the year as paid workers. ${ }^{185}$ The statute also prescribes that only the best three out of ten candidates were to be selected. This indicates that the very selection, which went along with the substantial benefit of tax exemption, meant a privileged distinction to the selected artisan and to his or her family. ${ }^{186}$

The question of organizational grouping is as difficult to answer in the case of artisans as in the case of merchants. In the context of discussing craftspeople, Barbieri-Low suggests that "Qin and Han legal statutes show that a group responsibility system resembling incipient guilds already existed in early imperial China." ${ }^{187}$ The expression used by the legal texts is the same as that of the state-imposed responsibility groupings of five people ( $w u$ 伍) that were also applied on all other commoners. ${ }^{188}$ For marketplace vendors, including craftspeople, it meant that if one member

180 Alternatively called jiang 匠.

181 Barbieri-Low 2007, 36-56.

182 Barbieri-Low 2007, 56-63.

183 Shiji 129.3274, trans. Watson 1993, 449.

184 This was the usual time length of commoners' conscript labor each year.

185 The latter arrangement (one month of conscript labor, paid labor for the rest of the year) was common practice under the Tang, but we do not have concrete corresponding evidence with regard to Han times.

186 Barbieri-Low and Yates 2015, 753-761 ("Statutes on Exemption from Taxes"), with n. 10 on 760-761 discussing the question regarding the exemption of the poll tax.

187 Barbieri-Low 2011a, 384.

188 On the responsibility groups among commoners, see also Leese-Messing, vol. 1, ch. 12.A, 140, 166. 
of the group violated rules (e.g., by avoiding fees or taxes), the other group members could be held responsible for not denouncing the former. Furthermore, vendors in official marketplaces - including craftspeople - seem to have been collocated on certain lanes (lie 列) based on their shared profession or product range. On each lane, a 'chief of the market lane' (liezhang 列長) was meant to supervise all other vendors of the same lane and denounce them, if applicable. ${ }^{189}$ Under certain circumstances, both of these state-enforced groupings may have resulted in collaborative activities that went beyond and defied the original function of mutual surveillance. But since we know next to nothing about how these groupings affected Qin and Han artisans' (as well as merchants') collective economic behavior, I would tentatively refrain from associating them with guilds. In a similar vein, interpretations of the potential use of the word hang 行 on some early imperial craft products - with hang being a later term for marketplace lanes, and ultimately the Tang term for guilds - as evidence for 'proto-guilds' must also be regarded as speculative. ${ }^{190}$

\section{VIII.2 Craftswomen}

Women constituted a substantial segment of the Qin and Han craft labor force. This went far beyond the much-idealized weaving work that women were supposed to contribute to self-sufficient farming households. Many wives of craftsmen certainly worked alongside or as assistants to their husbands, as is suggested by a pictorial stone showing a wheelwright being assisted in his professional work by a woman carrying a baby on her back. ${ }^{191}$ But there are also a number of references to women, especially widows, becoming independent artisans. ${ }^{192}$

The available evidence shows much more clearly that female workers were massively employed in government workshops. If interpreted correctly, the Han statute mentioned above even prescribes a quota preferring conscripted adult females over male and minor artisans in a ratio of two to one. This mirrored the state's demand for textile production and lacquer painting, both associated with female labor. ${ }^{193}$ Indeed, the vast majority of artisans whose names are incised on a group of lacquer vessels produced partly in private, partly in government workshops of the Qin peri-

\footnotetext{
189 For the according Qin and Han legal statutes on 'groups of five' on marketplaces and the 'chief of the market lane,' see Shuihudi Qin mu zhujian zhengli xiaozu 1990, 36 (slip no. 68); Hulsewé 1985, 53 (A45); Barbieri-Low and Yates 2015, 722-723 (no. 2 of the "Statutes on [Passes and] Markets”).

190 Cf. Barbieri-Low 2011a, 384-385; 2007, 129.

191 Barbieri-Low 2007, 93, 108.

192 Barbieri-Low 2007, 108-109; Ch'ü 1972, 54-55.

193 Barbieri-Low and Yates 2015, 758-759, including n. 9.
} 
od are identified as females. ${ }^{194}$ In Han lacquer inscriptions, many of which further mention each artisan's role in the production process, women's names also appear in relatively high-status positions, such as that of 'design painters' (huagong 畫工). On several inscribed vessels from an imperial workshop in Sichuan, one woman even appears as a 'scribe director' (lingshi 令史), a position entailing scribal and accounting functions and a substantial amount of responsibility to which she may have been promoted on the grounds of longtime experience as an artisan in the workshop. ${ }^{195}$ The quantitative productivity of female work, especially with regard to weaving, was a prominent theme of mathematical calculations presented in Han era mathematical handbooks, which may be taken as an indication of their acknowledged economic importance. ${ }^{196}$

\section{VIII.3 Craft Workshops}

The commonplace expressions for craft workshops during Qin and Han times were zuoshi 作室 ('fabrication chamber') and gongshi 工室 ('craft chamber'). Facilities ranged from small-scale private workshops operated by one or a few artisans to possibly factory-like, state-run production units employing hundreds or even thousands of workers. As for the highest reported staff numbers, the workshops of the government's 'Three [Seasons] Garments Office' in Qi reportedly employed thousands of workers each during the Former Han period. ${ }^{197}$ It is, however, not quite clear if all these (probably largely female) workers actually worked together in factory-like facilities or from home. ${ }^{198}$ Some text passages indicate that a state workshop for textile production in Shu (Sichuan) may have taken the form of a walled industrial village. ${ }^{199}$ Different forms of labor management and corresponding facilities, of course, may have existed side by side, depending on regional traditions and technological demand for certain products.

State-run workshops, usually referred to as 'craft offices' (gongguan 工官), produced a variety of products, including iron tools, weapons, luxury textiles, and exquisite tableware. Some of the state-produced products unearthed from tombs both inside and outside of China feature detailed quality control inscriptions, including not only dates and places of production, but also craftspeople's and supervisors' names

194 Barbieri-Low 2007, 110-114.

195 For these inscriptions (including English translations), see Y. Liu 2019b, 152-153. For certain jobs in the production of lacquer objects, such as gilding or core-carving, women's names have not been found at all. On many other (usually later) Han lacquer inscriptions, gender identification is impossible because of more rigid naming conventions. Barbieri-Low 2007, 113-114.

196 Chin 2014, 194-195.

197 See Gong Yu's memorial, translated in Barbieri-Low 2001, 405-409, esp. 408.

198 Barbieri-Low 2007, 110.

199 Wagner 2001, 38; Shu jin shihua bianxie zu 1979, 13-4, 83-5. 
along with the production step or management responsibilities. Some lacquer objects are inscribed with lists of more than ten people who were each involved in a specific task in the process of production and supervision. They thus testify to the high degree of labor division and vertical specialization in state-run workshops. ${ }^{200}$ Similar, albeit typically much shorter, inscriptions have also been found on products from other, presumably private, workshops. ${ }^{201}$ Furthermore, craftspeople in private workshops frequently used systems of customizable prefabrication, enabling off-site construction and stock production, e.g., by using standardized modules for stone monuments. ${ }^{202}$

Evidence for private workshops as places of knowledge transfer and education are scarce. According to epigraphic evidence, the staff of small-scale private workshops often involved specialized 'masters' (shi 師), e.g., master masons and master draftsmen in stone carving workshops, as well as 'apprentices' (di 弟), who were expected to carry on their masters' production traditions. ${ }^{203}$ A little more is known about the educational aspects of state workshops. Legal texts prescribe a probationary period of one year, after which the apprentice was supposed to produce half of the output of a full-fledged artisan, and a second year of training after which a full work quota was expected. Craftspeople achieving this goal earlier were supposed to be granted a monetary reward. Failing this goal after two years of training meant the apprentice was not accepted to work in a state workshop. ${ }^{204}$

By conscripting and hiring craftspeople from small-scale, private workshops to work in state workshops, and by training convict laborers as state artisans and leasing them out or selling them on the private labor market, ${ }^{205}$ a transfer of knowledge concerning production techniques and labor division could take place in both directions. These intersections between state and private production are likely to have facilitated wider spread and enhancement of sophisticated craft technologies during the early imperial era. ${ }^{206}$

\section{VIII.4 Industrial Entrepreneurs}

Transmitted texts indicate that craft production may not only have happened in state production facilities and smaller private workshops, but also under the leader-

200 For a collection of inscriptions on imperial lacquers, including English translations, see Y. Liu 2019b. On labor division, see Barbieri-Low 2001, especially ch. 4.III.

201 On the differentiation between government and private workshops, see the overview given in Leese-Messing, vol. 1, ch. 12.C.

202 Barbieri-Low 2007, 93-96.

203 Barbieri-Low 2007, 70-73.

204 The regulations did not differentiate between different types of craft with regards to their training needs. This was different from the later Tang regulations, which took into account differences in educational needs between individual crafts, for instance prescribing up to four years of training for the most difficult ones. Barbieri-Low 2007, 70-73.

205 On the latter, see Korolkov 2020, 364.

206 On technological developments, see further Leese-Messing, ch. 11, VII, this volume. 
ship of private actors who managed to establish production centers of considerable scale. The clearest indication of the relevance of such actors is provided by Sima Qian's Former Han account of 'money makers,' several of whom accumulated their wealth on the basis of flourishing businesses they owned or built up. Next to the primary producers of the salt and iron industries, Sima Qian also mentions businesses involving processed products that lent themselves to wealth accumulation when they were sold on large scales. Among Sima Qian's examples are products such as alcoholic beverages, jars of pickles, sauces, bean relish, syrups, felt mats, different kinds of fine textiles, as well as wooden, iron, and lacquered vessels. ${ }^{207}$ Since the historian only mentions the selling aspect explicitly, it is not quite clear whether or which of these products were also produced by entrepreneurs on a grand scale or if the entrepreneurs in this case rather acted as whole-sale traders of items produced by small-scale producers. While this needs to be kept in mind, one also needs to acknowledge that larger production units in both private and state contexts (such as in salt, iron, lacquer, and textile production) were potential models for private craft producers, and that knowledge transfer with regard to labor management was facilitated by the state's system of recruiting its craft labor force. It seems not implausible, therefore, to assume that larger private production facilities played a certain role in the production of at least some of the craft products. Transmitted historical records indeed mention wealthy families employing up to seven hundred servile handicraft workers whose produce served to grow the family fortune. ${ }^{208}$

\section{The Military}

\section{IX.1 Basic Economic Implications of Making War and Peace}

Military prowess and territorial expansion were not as closely and generally connected to the idea of Han emperorship as they were to rulership ideals in other societies like in Southeast Asia, the Roman Empire, or Hellenistic monarchies. This is not because things developed more peacefully in ancient China, but because a considerable part of imperial expansion - including centuries of intensive wars predated the early imperial period. During Han times, the interstate violence and destruction that had characterized the Warring States period was mostly a thing of the past. From an economic perspective, however, pre-imperial battles still had important ramifications: First, the fact that they had ultimately resulted in one side subjugating all others (first but temporarily the Qin, then lastingly the Han), was a major prerequisite for long-term peace and stability in the Han Empire's central

207 Shiji 129, trans. Watson 1993, 433-454; Nienhauser 2019, 261-309.

208 Hanshu 59.2652. 
regions that promoted economic prosperity and population growth. And second, long-term wars had entailed the 'creative destruction' of the old nobility, which facilitated social mobility and the rise of a new, increasingly wealth-based elite during the Former Han period. The latter's consumer behavior is in turn likely to have contributed to central economic processes such as the increasing importance of private markets and monetization.

That being said, even after the consolidation of the Han dynasty, troops were raised on the frontiers for both defensive and expansionist purposes. During certain times, such as the major expansionist phase under Emperor $\mathrm{Wu}$, this also involved massive campaigns. The scale of military endeavors was, however, highly unsteady and depended on individual emperors' priorities, as well as changing external and internal circumstances. The imperial wars were also of a different nature because they were now fought for regions that were much less densely populated and urbanized and partly used for pastoral rather than agricultural purposes. The motives for making war also varied from region to region and over time. While invasions into some regions promised economic profits through additional tribute or tax payments, acquisition of arable land for an increasing population, or by facilitating trade, other politically motivated deployments of troops (especially in the north and northwest) bore hardly any economic opportunities from a central fiscal point of view and could even evolve into a long-term economic burden on the state budget. ${ }^{209}$ Different frontier regions varied considerably with regard to their potential to become economically independent from or even fiscally beneficial to the core regions.

In any case, both expansionist campaigns and long-term military presence in frontier regions had important economic ramifications. Military consumption and redistribution of supplies were a challenge that required major structural changes, including new fiscal policies. Furthermore, expansionism resulted in the monetization of regions in which money had not played a role before. Military occupation further created new spaces of economic interaction and potential for increasing connectivity.

\section{IX.2 Consumption, Redistribution, and Monetization}

The military was essentially a large consumer of manpower and provisions. Members of the Han army were drawn from three main sources. They served as enlisted conscripts (with a service theoretically comprising two years, including one on the

209 For these aspects of expansionism, see Leese-Messing, vol. 1, ch. 4, IV.4.4, and vol. 1, ch. 12.A, II.5. As an example of economically burdensome undertakings, transmitted texts mention that during the period between 107 and 118 CE alone, the cost of defending Liang Region (Liangzhou), which comprised the northwestern commanderies including the Hexi corridor, cost the central government over 24,000 million coins. Yü 1967, 61. 
frontier), ${ }^{210}$ as voluntary and paid recruits, or as (partly amnestied) convicts. The proportions of these three sources are unclear, just as the whole system of Han conscription and other forms of recruitment are still poorly understood. At least during the early Han period, conscripts appear to have constituted the largest part of the forces, whereas their importance decreased during later periods when they were increasingly replaced by paid volunteers, many of whom were ethnic nonChinese. ${ }^{211}$

Directly or indirectly supplying these people on the frontiers with food, textiles, cavalry horses, weapons, and other equipment demanded surplus production by other actors, especially agriculturalists. Since expansion moved toward regions like the northern steppe and desert regions with limited or untapped agricultural potential, campaigns and long-term stationing of border-guarding troops necessarily relied on surpluses produced in the inner regions of the empire and the redistribution of these surpluses to the frontiers.

In the early decades of Han rule, when the central government largely avoided larger military endeavors, such large-scale redistribution processes accordingly were not integrated into social, political, and economic structures. The eventual outbreak of massive frontier warfare under Emperor $\mathrm{Wu}$, therefore, demanded drastic structural changes in supply mechanisms. New fiscal policies were introduced, including various ad hoc measures. These demanded contributions from wealthy actors especially, which ranged from provisioning of grain in exchange for official ranks and titles to sharply rising taxes for merchants to disappropriation of industrial entrepreneurs' and wealthy landowners' property. ${ }^{212}$ All of these measures provoked political resistance and partial economic disruption in those central commanderies whose spokesmen felt particularly burdened by them. Some of these new policies, especially the introduction of monopolies, yet developed into longer-term expansions of the fiscal budget that facilitated military expenditure on a more regular basis. Nevertheless, imperialism and concomitant large-scale redistribution mechanisms were never as firmly integrated into the political and economic structure of the empire as they were in the Roman Empire.

In order to shift the fiscal burden from the center to frontier regions and avoid costly long-distance transport of supplies, the Han government established settlements called 'agricultural garrisons' (tuntian 屯田) in the northwest as far as the Tarim Basin. Under this policy, which began under Emperor $\mathrm{Wu}$ and was continued

210 According to one of the interpretations of the transmitted source material, one of the two years was spent for training in the conscripts' home commandery, and a second one in active service, e.g., at the frontier. A different interpretation holds that conscripts spent two years in the interior and were additionally required to serve three days per year on the frontier, to be rendered cumulatively.

211 Loewe 1967, 1:77-82. See also Leese-Messing, vol. 1, ch. 4, IV.4.7.

212 Sima Qian describes the series of ever-new measures to secure revenues in Shiji 30, trans. Watson 1993, 61-85. 
and extended under his successors, soldiers took over the double task of guarding the frontiers and supplying them with the produce of newly reclaimed and often intensively irrigated agricultural land. ${ }^{213}$

Yet it is still rather uncertain how the soldiers and other military personnel were provisioned. Serving as a regular military conscript or convict was generally not associated with monetary remuneration, so that state supplies of clothing, food, weapons, etc. must have played a major role. This must have been especially true for ongoing campaigns, even though evidence in this regard is scarce. We have considerably more information about long-term garrison sites, especially from the northwestern frontier region including the Hexi corridor and Juyan in particular. Local centers of distribution and granaries in this area kept detailed notes on their stores. Records of food rations and recipients suggest that conscripted garrison soldiers and their families were provided with regular grain and salt supplies, as well as clothing. The recorded quantities suggest allowances sufficient for subsistence, and are therefore a further indication that this group of common soldiers did not receive monetary payment by the state. ${ }^{214}$ It is hard to tell to what extent this changed with the state's increasing reliance on paid recruits, as we lack evidence of their precise role in the military and the form of their payment. At least one document refers to the monetary payment of recruits - of Xiongnu descent, in this case. ${ }^{215}$ Moreover, even soldiers who did not enjoy monetary pay could find ways to participate in the monetary economy, as is shown by instances of soldiers selling their clothes, which they had probably received from the government. ${ }^{216}$ Nevertheless, with their rather meager income and relatively short terms of service on the frontier, ${ }^{217}$ the soldiery is likely to have played a much smaller economic role as consumer and driver of state-issued coinage than in the Hellenistic and Roman empires. ${ }^{218}$ They were, however, not the only frontier inhabitants. The documents show very clearly that both civilian officials and military officers, many of whom are likely to have spent longer periods of time in the regions, were largely paid in cash. ${ }^{219}$ Their salaries were reckoned by the month, but cumulative pay (e.g., three months)

213 For evidence on agricultural garrisons from excavated texts, as well as according scholarship on the broader topic, which is also based on evidence from transmitted texts, see Ma, vol. 1, ch. 12.B, 533-534.

214 Rations varied according to status, sex, and age of the individual, as well as to the type of grain. They ranged between 1.16 and 3.3 shi (22 and 65.6 liters) per month. Issues of animal fodder are also recorded on some documents. E.g., Loewe 1967, 1:92-94; Scheidel 2009, 183.

215 H. Wang 2004, 52.

216 See, for instance, the example given in Ma, vol. 1, ch. 12.B, 535-537.

217 See, e.g., Sanft 2019, 34-35.

218 Cf. Fabian and Weaverdyck, ch. 3.A, IV, this volume.

219 Much lesser references refer to payment in textiles, and few others in grain, and one in salt. H. Wang 2004, 48-51. 
was very common. ${ }^{220}$ Documents recording arrears of salary payment identify the sources of money in these cases as the treasuries of the capital city or a certain local government in the inner regions of the empire. This may indicate that, in cases of local monetary shortage, the central government was prepared to send coins to the northwest for their servicemen. Other documents show, however, that at least during certain periods, border officials were allowed to cast standard Han wuzhu coins locally. ${ }^{221}$

Monetization processes in frontier regions were often tightly connected to Han military and administrative presence. The northwestern region is again a particularly clear example of this. In the Hexi corridor, for instance, there is no evidence for coinage from the time before the Qin Empire, whereas Han wuzhu coins abound in the region. It is clear that under Han rule the use of money in this frontier zone came to be well established. Excavated texts sometimes refer to transactions involving hundreds of thousands and even millions of coins. ${ }^{222}$ They mention monetary transactions among private individuals (with commodities ranging from items of everyday use to irrigated fields and hired labor) ${ }^{223}$ as well as monetary purchases of goods by government institutions. For example, administrative documents from the state-run postal station at Xuanquan 懸泉 near Dunhuang 敦煌 record the purchase of chickens that were used for meals provided for traveling state officials and diplomatic delegations. ${ }^{224}$ The use of Han coinage spread with Han military presence beyond the Hexi corridor into the Tarim Basin, where it further served as an inspiration for the famous Sino-Kharoșthi coins of Khotan. ${ }^{225}$ The commonplace use of money likely had stimulating effects on exchange in these and other frontier regions.

\section{IX.3 Connectivity}

In some frontier regions of the empire, Han military and administrative presence radically changed the landscape and infrastructure, as well as the demographic and ethnic composition. The Hexi corridor changed from a sparsely populated area of mainly pastoralist use with barely any settlements to a region with hundreds of thousands of settled inhabitants. Most of them came from central parts of the Han Empire to the frontier, where they built settlements, initiated large-scale irrigation projects and land reclamation for intensive agricultural use, and built roads and border fortifications. Changes in other frontier regions, such as in the south, were

220 H. Wang 2004, 49. Individual soldiers' officially submitted complaints regarding outstanding salary payments and food rations have also been found (Loewe 93-94, 97).

221 H. Wang 2004, 49-50; 2007, 67-68.

222 H. Wang 2007, 64.

223 See, for instance, the examples given in H. Wang 2007, 74-75.

224 Lee Kim 2016, 578-579.

225 H. Wang 2004, 24-27, 37-38. 
definitely less dramatic in some of these respects, but the increase of infrastructural investments and connectivity over large distances that went along with military campaigns and the stationing of military and administrative personnel applied to frontier regions in all directions. Parts of the road network that the Qin and Han Empires' core regions inherited from the Warring States period must already be seen as a byproduct of pre-imperial warfare and its infrastructural demands to enable troop movement and provisioning. These had lasting effects on interregional mobility. Extensions of this large inner road network in all directions during the early imperial era was again largely initiated in the context of military advance.

Military presence in frontier regions brought inhabitants of widely separated regions together in one place. Excavated documents have highlighted the broad range of geographic origins among soldiers, who were recruited in the central parts of the empire in order to serve on the frontiers. This diversity can also be seen in the higher echelons of frontier societies, whose members came there as officials or higher military personnel by means of an empire-wide recruitment system. All of these people now lived and worked together in places far away from their home commanderies and were furthermore brought into direct contact with native people of yet other cultural and economic backgrounds (e.g., former or current pastoralists). ${ }^{226}$ The constellation of challenges posed by both unfamiliar landscapes and the diverse population may have borne a considerable potential for innovation and mutual knowledge transfer, even though concrete manifestations of such are hard to pin down. One suggested field of knowledge transfer is the spread of basic literacy, or at least increased familiarity with textual culture among common garrison personnel. They may have been confronted with texts like written instructions more intensively than at home, where many of them would ultimately return with the experiences they gained on the frontier. ${ }^{227}$ Yet taking into account the relative short terms of service in the case of conscripts, it remains questionable to what extent this exposure indeed fostered an overall increase in literacy rates and potential for socioeconomic mobility among the empire's common people.

One frequently mentioned economic aspect of military and subsequent administrative presence in frontier regions is their supposed protection of trade routes. Again, this function has been associated particularly with the Hexi region and its role as a passageway to Central Asia. ${ }^{228}$ Some differentiation is due in this context. Certainly, the new presence of settlements and masses of people, as well as their defense against external invaders through military fortifications, created unprecedented spaces for economic interactions in the region, including private trade between settlers and native locals. The newly established settlements and marketplaces probably facilitated travel by offering good opportunities to acquire lodging

226 On the northwestern frontier society, see Giele 2018; Li 2003.

227 Sanft 2019.

228 For more details on this matter, see Weaverdyck et al., ch. 7, VI, this volume. 
and food. But the generalizing statements about the alleged trade route protection of state institutions in the form of garrisons, fortifications, and relay stations in the region gives the wrong impression that the state's establishment of these institutions was aimed at the particular purpose of enabling private long-distance trade with Central Asian polities. As extensive finds of administrative documents have shown, the state-run relay stations like the one at Xuanquan provided lodging, food, fodder, and postal services to traveling officials and large diplomatic delegations, ${ }^{229}$ but there is no indication whatsoever that private merchants could use these services. These institutions provided opportunities for goods to be exchanged over large distances in the context of diplomacy under the direction of the court, which was largely politically motivated. Certainly, traveling officials making use of these facilities could also have used these trips for private trading activities to a certain extent. But these particular forms of exchange included only very special groups of actors while excluding most others. The fundamental purposes of the military and infrastructural institutions were, after all, political rather than commercial. Their role in supporting private, long-distance trade must, therefore, not be overrated.

\section{Diplomatic Delegations}

In comparison to other groups of actors discussed in this chapter, foreign delegations sent by the Han court involved relatively few people and were acting sporadically rather than constantly. Nevertheless, their activities are crucial when it comes to long-distance exchange and, more concretely, the question of how luxury products of the Han Empire ended up in distant places.

The history of envoys (shi 使 or shizhe 使者) goes back to pre-imperial times. They already played an important role in the interactions between the individual polities of the Spring and Autumn and Warring States periods. However, the geographic reach and size of delegations did increase sharply during the Han period, and their role changed accordingly. From the beginning of the Han period, envoys were sent to the Xiongnu chanyus in order to negotiate peace treaties that involved the presentation of lavish gifts, hostages, and princesses for marriage alliances. ${ }^{230}$ Subsequently, foreign diplomatic relations were widely extended during the reign of Emperor Wu, especially toward polities of the Tarim Basin and Central Asia. For Emperor Wu's time, Sima Qian's The Scribe’s Records (Shiji 史記) informs us that:

The largest of the delegations to foreign states numbered several hundred persons, while even the smaller parties included over 100 members ... Later, as the envoys became more accus-

229 On these, see the following section.

230 See Leese-Messing, vol. 1, ch. 4, 174-175. 
tomed to the route, the number was gradually reduced. In the course of one year anywhere from five or six to over ten delegations would be sent out.

諸使外國一輩大者數百, 少者百餘人 [...]。其后益習而衰少焉。漢率一歲中使多者十餘, 少者五六輩。231

The selection of envoys probably rested on individual decisions, as the Han court did not provide for specialized diplomats. ${ }^{232}$ Sima Qian's sarcastic remark about Emperor Wu's envoys to distant lands all being sons of poor families who were primarily interested in embezzling the entrusted diplomatic gifts and selling them along the way ${ }^{233}$ is neither to be discarded as an individual piece of evidence nor to be hastily generalized as indicating a standard phenomenon. In most cases, we simply do not know much about a delegation's composition. More specialized members of delegations also included translators and connoisseurs of local customs such as subject foreigners. Apart from being sent from the central court directly, envoys (other than large delegations) could also be sent off by governors of frontier commanderies on imperial permission. ${ }^{234}$

It has been amply demonstrated that, neither for the Han nor for their diplomatic partners, were diplomatic missions just a 'cloak for trade. ${ }^{235}$ In fact, diplomatic relations and motivations on all sides were much more complex. For the Han court, delegations to foreign countries were primarily seen as political. High-value gifts such as exquisite silks were not necessarily exported in the hope of material reciprocity but rather with the hope for peaceful relations, military alliance, and ideally, the other side's recognition of Han superiority. Indeed, the historical accounts suggest that the value of goods exported via diplomatic channels was typically considerably larger than what came back as 'tribute. ${ }^{236}$ Nevertheless, transmitted sources suggest that an interest in particular goods, both on the part of the Han emperors and on the part of the envoys themselves, did accompany at least some of these missions. In some missions they even played a central role, as was the case in Emperor Wu's approaches to Dayuan and the Wusun from whom he sought to acquire good horses for restocking his cavalry forces. ${ }^{237}$

231 Shiji 123.3170, trans. Watson 1993, 240-241 (with modifications). See also Nienhauser 2019, 7879.

232 Selbitschka 2015a, 70-71.

233 Shiji 123.3171. Cf. Hanshu 61.2695, where Ban Gu left out the remark on the envoys' poor family background. On this passage, see also Leese-Messing, vol. 1, ch. 12.A, 509-510.

234 See the instance of the governor of Wuwei Commandery (in the Hexi corridor) sending an envoy (or several envoys) to the Northern Xiongnu to invite them to the court, as presented in Yü 1967, 103.

235 According arguments, especially with regard to foreign delegations, had been proposed by Yü 1967, esp. 59, 144.

236 Van Ess 2012; Selbitschka 2015a.

237 Shiji 123.3170, trans. Watson 1993, 240; Nienhauser 2019, 78. 
From an economic viewpoint, various functions can be associated with the Han envoys. First, they were trusted agents in the transmission of often enormous amounts of valuable gifts from and to the Han court. Many of the most exclusive luxury goods left the Han Empire through the bottleneck of Han delegations and their foreign counterparts rather than through private trade. Second, envoys do at times appear as people that engaged in private trade themselves alongside their diplomatic tasks, and sometimes thwarted them. ${ }^{238}$ The extent of this private business is hard to fathom, but it was most likely limited and dependent on the socioeconomic composition of individual delegations and their expected official remuneration, both of which are likely to have varied from case to case. Third, envoys can be considered as long-distance transmitters of market information. At the Han court, diplomatic gifts sent by and to foreign rulers were not always discussed solely with regard to their 'appropriateness' for diplomatic purposes but also with regard to their economic value as commodities. ${ }^{239}$ For the governments on both ends of a long-distance journey, envoys must have been a very valuable, if not the only, source of knowledge about supply and demand. Quite a few passages in the dynastic histories mention Han envoys informing the emperor about the products of, and goods in demand in, other countries. ${ }^{240}$ It can hardly be doubted that such information had practical implications for the choice of goods exchanged as diplomatic gifts, thereby dissolving, to a certain extent, the strict boundary between political gift-giving and market-based trade.

\section{Conclusion}

This chapter has introduced a range of major economic actors in the early Chinese empires, including types of individual actors as well as organizations of actors. It has described some of the major roles that each of them played in society and how these roles shaped their economic behavior in the fields of consumption, production, distribution, and coordination. All these groups intersected each other: Local elites included both primary producers and traders, and some of them were also acting as members of local government institutions. Farmers were often part of the military, and members of all actor groups were typically also household members. Members of the imperial court, along with other types of actors, could eventually

238 See Leese-Messing, vol. 1, ch. 12.A, 508-511.

239 On this point, see Leese-Messing, ch. 12.A, vol. 1., 515-516.

240 For instance, according to Shiji 123.3168 (trans. Watson 1993, 238; Nienhauser 2019, 75), Zhang Qian 張騫 (195-114 BCE) told Emperor Wu that foreign peoples such as the Wusun were "greedy for Han wealth and goods," and according to Shiji.123.3174 (trans. Watson 1993, 245; Nienhauser 2019, 86), members of later delegations told him about the wonderful horses that the Dayuan possessed. The delegation reports, on which the depictions of foreign states in dynastic histories are largely based, offer many more examples of concrete products of certain countries or regions. 
find themselves in delegations of envoys to foreign countries. In this discussion, the impact of state institutions has crystallized in various ways, but has been shown to have shaped the behavior of economic actors across the whole spectrum to a considerable degree. The impact of these institutions and of other 'tools' on the complex interplay between actors, and therefore on larger economic processes, will be examined in chapter 15 .

\section{References}

Barbieri-Low, A. J. 2001. "The organization of imperial workshops during the Han dynasty." PhD diss., Princeton University.

-. 2007. Artisans in early imperial China. Seattle, WA: University of Washington Press.

-. 2011a. "Craftsman's literacy: Uses of writing by male and female artisans in Qin and Han China." In L. Feng and D. P. Branner (eds.), Writing and literacy in early China: Studies from the Columbia Early China Seminar, 370-400. Seattle, WA: University of Washington Press.

-. 2011b. "Model legal and administrative forms from the Qin, Han, and Tang and their role in the facilitation of bureaucracy and literacy." Oriens Extremus 50, 125-156.

-. 2017. "Becoming almost somebody: Manumission and its complications in the early Han Empire." In J. Bodel and W. Scheidel (eds.), On human bondage: After slavery and social death, 122-135. Malden, MA: Wiley Blackwell.

Barbieri-Low, A. J. and R. D. S. Yates. 2015. Law, state, and society in early imperial China: A study with critical edition and translation of the legal texts from Zhangjiashan tomb no. 247. 2 vols. Leiden: Brill.

Bertrand, A. 2010. "The hydraulic systems in Turfan (Xinjiang)." The Silk Road Newsletter 8, 2741.

Bielenstein, H. 1979. "The restoration of the Han dynasty, volume IV: The government." Bulletin of the Museum for Far Eastern Antiquities 51, 1-300.

-. 1980. The bureaucracy of Han times. Cambridge: Cambridge University Press.

Brashier, K. E. 2011. Ancestral memory in Early China. Cambridge, MA: Harvard University Asia Center.

-. 2014. Public memory in Early China. Cambridge, MA: Harvard University Asia Center.

Bray, F. 1979. "Agricultural technology and agrarian change in Han China." Early China 5, 3-13.

-. 1981. "Millet cultivation in China: A historical survey." Journal d'agriculture traditionnelle et de botanique appliquée 28.3, 291-307.

Chen Songchang 陳松長, ed. 2015. Yuelu shuyuan cang Qin jian 岳麓書院藏秦簡 [Qin bamboo slips from the Yuelu Academy collection]. Vol. 4. Shanghai: Shanghai cishu chubanshe.

Chen Wei 陳偉, ed. 2012. Liye Qin jiandu jiaoshi 里耶秦简牍校释 [A critical and annotated edition of the Qin bamboo and wooden slips from Liye]. Vol. 1. Wuhan: Wuhan daxue chubanshe.

Chin, T. T. 2010. “Defamiliarizing the foreigner: Sima Qian's ethnography and Han-Xiongnu marriage diplomacy." Harvard Journal of Asiatic Studies 70.2, 311-354.

-. 2014. Savage exchange: Han imperialism, Chinese literary style, and the economic imagination. Cambridge, MA: Harvard University Asia Center.

Ch'ü, T. 1972. Han social structure. J. L. Dull (ed.). Seattle, WA: University of Washington Press.

Cook, C. 2006. Death in ancient China: The tale of one man's journey. Leiden: Brill.

Di Cosmo, N. 1994. "Ancient Inner Asian nomads: Their economic basis and its significance in Chinese history." Journal of Asian Studies 53.4, 1092-1126. 
Ebrey, P. 1980. “Later Han stone inscriptions." Harvard Journal of Asiatic Studies 40.2, 325-353.

-. 1986. "The economic and social history of Later Han." In D. Twitchett and M. Loewe (eds.), The Cambridge history of China. Vol. 1, 608-648. Cambridge: Cambridge University Press.

Gale, E. M., trans. 1967. Discourses on salt and iron: A debate on state control of commerce and industry in ancient China, Chapters I-XXVIII. Taipei: Ch'eng Wen.

Gao Kai 高凯. 2008. “Cong Juyan Han jian kan Han dai de 'nü hu' wenti” 从居延汉简看汉代的 '女户”问题 [The question of 'female households' from the perspective of the Han slips from Juyan]. Shixue yuekan 史学月刊 9, 82-92.

Gao Min 高敏. 2003. “Cong Zhangjiashan Han jian 'Ernian lüling' kan Xi-Han qianqi de tudi zhidu: Du 'Zhangjiashan Han mu zhujian' zhaji zhi san” 從張家山漢簡《二年律令》看西漢前期的 土地制度：讀《張家山漢墓竹簡》札記之三 [The land tenure system of the early Western Han period based on the 'Ernian lüling' from the Zhangjiashan bamboo slips]. Zhongguo jingji shi yanjiu 中国经济史研究, no. 3, 143-147.

Giele, E. 2018. “Kandai seihoku henkyō hōbigun no shakai kōzō: Shutsudo shiryō no bunseki ni motozuku hōhōronteki kōsatsu” 漢代西北辺境防備軍の社会構造: 出土史料の分析に 基づく方法論的考察 [The composition of the northwestern border society during Han times: Methodological considerations based on the analysis of excavated documents]. In Miyake Kiyoshi 宮宅潔 (ed.), Taminzoku shakai no gunji tōchi: shutsudo shiryō ga kataru chūgoku kodai 多民族社会の軍事統治: 出土史料が語る中国古代, 1-27. Kyoto: Kyōto Daigaku Gakujutsu Shuppankai.

Hanshu 漢書 [Documents of the Han]. 1962. Composed by Ban Gu 班固 (32-92 CE). Beijing: Zhonghua shuju.

Hinsch, B. 1998. "Women, kinship, and property as seen in a Han dynasty will.” T'oung Pao 84.1, 1-20.

-. 2011. Women in early imperial China. 2nd ed. Lanham, MD: Rowman \& Littlefield.

Hou Hanshu 後漢書 [Documents of the Later Han]. 1965. Composed by Fan Ye 范瞱 (398-445 CE). Beijing: Zhonghua shuju.

Hsing, I-tian. 2014. "Qin-Han census and tax and corvée administration: Notes on newly discovered materials." In Y. Pines, G. Shelach, L. Falkenhausen, and R. D. S. Yates (eds.), Birth of an empire: The state of Qin revisited. Berkeley, CA: University of California Press.

Hsu, C. 1980. Han agriculture: The formation of the early Chinese agrarian economy (206 BC$A D$ 220). J. L. Dull (ed.). Seattle, WA: University of Washington Press.

Huang, H. T. 2000. Science and civilisation in China. Vol. 6, Biology and biological technology. Part V, Fermentations and food science. Cambridge: Cambridge University Press.

Hulsewé, A. F. P. 1985. Remnants of Ch'in law: An annotated translation of the Ch'in legal and administrative rules of the 3rd century BC discovered in Yün-Meng Prefecture, Hu-Pei Province, in 1975. Leiden: Brill.

Hung, W. 1995. Monumentality in early Chinese art and architecture. Stanford, CA: Stanford University Press.

Kiser, E. and Y. Cai. 2003. "War and bureaucratization in Qin China: Exploring an anomalous case." American Sociological Review 68.4, 511-539.

Korolkov, M. 2012. "Greeting tablets' in early China: Some traits of the communicative etiquette of officialdom in light of newly excavated inscriptions." T'oung Pao 98.4/5, 295-348.

-. 2016. "Calculating crime and punishment: Unofficial law enforcement, quantification, and legitimacy in early imperial China." In "The New Ancient Legal History." Special issue, Critical Analysis of Law 3.1, 70-86.

-. 2020. "Empire-building and market-making at the Qin frontier: Imperial expansion and economic change, 221-207 BCE." PhD diss., Columbia University.

-. 2021. "Between command and market: Credit, labour, and accounting in the Qin Empire (221207 BCE)." In E. Sabattini and C. Schwermann (eds.), Between command and market: Economic thought and practice in Early China, 160-241. Leiden: Brill. 
Korolkov, M. and A. Hein. 2020. "State-induced migration and the creation of state spaces in early Chinese empires: Perspectives from history and archaeology." Journal of Chinese History, 1-23. https://doi.org/10.1017/jch.2020.45.

Kost, C. 2017. "Heightened receptivity: Steppe objects and steppe influences in royal tombs of the Western Han dynasty." Journal of the American Oriental Society 137.2, 349-381.

Kuhn, D. 1995. "Silk weaving in ancient China: From geometric figures to patterns of pictorial likeness." Chinese Science 12, 77-114.

Ledderose, L. 2000. Ten thousand things: Module and mass production in Chinese art. Princeton, N): Princeton University Press.

Lee Kim, M. 2016. "Discrepancy between laws and their implementation: An analysis of granaries, statutes, and rations during China's Qin and Han periods." Journal of the Economic and Social History of the Orient 59.4, 555-589.

Lewis, M. E. 2006. The construction of space in early China. Albany, NY: State University of New York Press.

-. 2007. The early Chinese empires: Qin and Han. Cambridge, MA: Belknap Press of Harvard University Press.

-. 2009. "Gift circulation and charity in the Han and Roman empires." In W. Scheidel (ed.), Rome and China: Comparative studies in ancient world empires, 121-136. Oxford: Oxford University Press.

-. 2015a. "Early imperial China, from the Qin and Han through Tang." In A. Monson and W. Scheidel (eds.), Fiscal regimes and the political economy of premodern states, 282-307. Cambridge: Cambridge University Press.

-. 2015b. "Public spaces in cities in the Roman and Han Empires." In W. Scheidel (ed.), State power in ancient China and Rome, 204-229. Oxford: Oxford University Press.

Li, Y., M. J. Storozum, X. Wang, and W. Guo. 2017. "Early irrigation and agropastoralism at Mohuchahangoukou (MGK), Xinjiang, China.” Archaeological Research in Asia 12, 23-32.

Li Zhenhong 李振宏. 2003. Juyan Han jian yu Han dai shehui 居延漢簡與漢代社會 [The Han documents from Juyan and the Han society]. Beijing: Zhonghua shuju.

Liu Xinning 劉欣寧. 2007. You Zhangjiashan Han jian 'Ernian lüling' lun Han chu de jicheng zhidu 由張家山漢簡《二年律令》論漢初的繼承制度 [A study of the inheritance system during the early Han period based on the "Statutes and Ordinances of the Second Year" on bamboo slips from Zhangjiashan]. Taipei: Guoli Taiwan daxue.

Liu, Y. 2019a. "Emblems of power and glory: The Han-period Chinese lacquer wares discovered in the borderlands." In P. Frick and A. Kieser (eds.), Production, distribution and appreciation: New aspects of East Asian lacquer ware, 30-63. Leiden: Brill.

-. 2019b. "Han-period official lacquers excavated from archaeological sites." In P. Frick and A. Kieser (eds.), Production, distribution and appreciation: New aspects of East Asian lacquerware, 152-195. Leiden: Brill.

Liu Zenggui 劉增貴. 1980. Han dai hunyin zhidu 漢代婚姻制度 [The marriage system of the Han era]. Taipei: Huashi chubanshe.

Loewe, M. 1967. Records of Han administration. 2 vols. Cambridge: Cambridge University Press.

-. 1974. Crisis and conflict in Han China, 104 BC to AD 9. London: Allen \& Unwin.

-. 1985. "Attempts at economic co-ordination during the Western Han dynasty." In S. R. Schram (ed.), The scope of state power in China, 237-267. London: School of Oriental and African Studies.

-. 1992. "The imperial tombs of the Former Han dynasty and their shrines." T'oung Pao 78.4/5, 302-340.

-. 1999. "The imperial way of death in Han China." In J. P. McDermott (ed.), State and court ritual in China, 81-111. Cambridge: Cambridge University Press.

-. 2004. The men who governed Han China: Companion to a biographical dictionary of the Qin, Former Han and Xin periods. Leiden: Brill. 
-. 2010. "Social distinctions, groups and privileges." In M. Nylan and M. Loewe (eds.), China's early empires: A re-appraisal, 296-307. Cambridge: Cambridge University Press.

-. 2015. "The tombs built for Han Chengdi and migrations of the population." In M. Nylan, G. Vankeerberghen, and M. Loewe (eds.), Chang'an 26 BCE: An Augustan age in China, 201217. Seattle, WA: University of Washington Press.

-. 2017. "Displaced persons in Han China and the so-called 'Mausoleum Towns." In T. 0. Höllmann, S. Müller, and A. Selbitschka (eds.), Über den Alltag hinaus: Festschrift für Thomas O. Höllmann zum 65. Geburtstag, 107-120. Wiesbaden: Harrassowitz.

Luo, L., X. Wang, J. Liu, H. Guo, R. Lasaponara, W. Ji and C. Liu. 2017. "Uncovering the ancient canal-based tuntian agricultural landscape at China's northwestern frontiers." Journal of Cultural Heritage 23, 79-88.

Ma, T. W. 2017. "Scribes, assistants, and the materiality of administrative documents in Qin-Early Han China: Excavated evidence from Liye, Shuihudi, and Zhangjiashan." T'oung Pao 103.45, 297-333.

Miyake Kiyoshi 宮宅潔. 2013. “Han dai guanliao zuzhi de zuixia ceng: 'guan’ yu ‘min’ zhijian” 漢代官僚組織的最下層: “官”與 “民”之間 [The lowest tier of the Han bureaucratic organization: Between 'officials' and 'people']. Zhongguo gudai falü wenxian yanjiu 中國古代法律文獻研究, no. 7, 127-161.

Nienhauser, W. H., ed. 1994. The Grand Scribe's records. Vol. 1, The basic annals of Pre-Han China. Bloomington, IN: Indiana University Press.

-. 2019. The Grand Scribe's records. Vol. 11, The memoirs of Han China, Part 4. Bloomington, IN: Indiana University Press.

Nylan, M. 2005. "Toward an archaeology of writing: Text, ritual, and the culture of public display in the classical period (475 BCE-220 CE)." In M. Kern (ed.), Text and ritual in Early China, 349. Seattle, WA: University of Washington Press.

-. 2010. “Administration of the family (Qihuai bisi 齊懷必死)." In M. Nylan and M. Loewe (eds.), China's early empires: A re-appraisal, vol. 67, 266-295. Cambridge: Cambridge University Press.

Pirazzoli-t'Serstevens, M. 2010. “Urbanism." In M. Nylan and M. Loewe (eds.), China's early empires: A re-appraisal, 169-185. Cambridge: Cambridge University Press.

Qianfu lun jian jiaozheng 潛夫論箋校正 [Comments of a Recluse with collated commentaries]. Composed by Wang Fu 王符 (ca. 85-163 CE). Collation of commentaries by Wang Jipei 汪繼培 and Peng Duo 彭鐸. Beijing: Zhonghua shuju, 1997.

Quan Hou Han wen 全後漢文 [Complete Later Han prose]. Compiled by Yan Kejun 嚴可均 (17621843). Vol. 2 of Quan shanggu sandai Qin Han Sanguo Liuchao wen 全上古三代秦漢三國 六朝文. 9 vols. Taibei: Shijie shuju, 1969.

Rawson, J. 1998. "Ewige Wohnstätten: Die Gräber des Königs von Nan Yue und der kaiserlichen Prinzen in Ostchina." In M. Prüch (ed.), Schätze für König Zhao Mo: Das Grab von Nan Yue, 80-95. Heidelberg: Umschau/Braus.

-. 1999. "The eternal palaces of the Western Han: A new view of the universe." Artibus Asiae 59.1/2, 5-58.

-. 2012. "The Han Empire and its northern neighbours: The fascination of the exotic." In J. C. S. Lin (ed.), The search for immortality: Tomb treasures of Han China, 23-36. New Haven: Yale University Press.

Sanft, C. 2019. Literate community in early imperial China: The northwestern frontier in Han times. Albany NY: State University of New York Press.

Scheidel, W. 2009. "The monetary systems of the Han and Roman Empires." In W. Scheidel (ed.), Rome and China: Comparative studies in ancient world empires, 137-207. Oxford: Oxford University Press.

-. 2017. "Slavery and forced labour in Early China and the Roman world." In H. J. Kim, F. Vervaet, and S. Adalı (eds.), Eurasian empires in antiquity and the early Middle Ages: Contact and 
exchange between the Graeco-Roman World, Inner Asia and China, 133-150. Cambridge: Cambridge University Press.

Selbitschka, A. 2015a. "Early Chinese diplomacy: 'Realpolitik' versus the so-called tributary system." Asia Major 28.1, 61-114.

-. 2015b. "Miniature tomb figurines and models in pre-imperial and early imperial China: Origins, development and significance." World Archaeology 47.1, 20-44.

-. 2018a. "Genuine prestige goods in mortuary contexts: Emulation in polychrome silk and Byzantine solidi from northern China." Asian Perspectives 57.1, 2-50.

-. 2018b. "Sacrifice vs. sustenance: Food as a burial good in late pre-imperial and early imperial Chinese tombs and its relation to funerary rites." Early China 41, 179-243.

Shangqiu diqu wenhua ju 商丘地区文化局 and Yongcheng xian wenhua guan 永城县文化馆. 1990. “Henan Yongcheng Qianyao Handai shishi mu” 河南永城前窑汉代石室墓 [A Han-era stone-chamber tomb from Qianyao, Yongcheng, Henan]. Zhongyuan wenwu 中原文物, no. 1, 7-12.

Shiji 史記 [The Scribe’s Records]. 1959. Composed by Sima Qian 司馬遷 (145 or 135-ca. 87 BCE). Beijing: Zhonghua shuju.

Shu jin shihua bianxie zu 蜀锦史话编写组. 1979. Shu jin shihua 蜀锦史话 [A history of Shu brocade]. Chengdu: Sichuan renmin chubanshe.

Shuihudi Qin mu zhujian zhengli xiaozu 睡虎地秦墓竹簡整理小組. 1990. Shuihudi Qin mu zhujian 睡虎地秦墓竹簡 [Bamboo slips from a Qin tomb at Shuihudi]. Beijing: Wenwu chubanshe.

Sterckx, R. 2015. "Ideologies of the peasant and merchant in Warring States China." In Y. Pines and M. Kern (eds.), Ideology of power and power of ideology in early China, 211-248. Leiden: Brill.

Su Weiguo 苏卫国. 2010. Qin Han xiangting zhidu yanjiu: Yi xiangting geju de zhongshi wei zhongxin 秦汉乡亭制度研究: 以乡亭格局的重释为中心 [A study on the Qin and Han system of districts and guard posts: With a focus on the spatial distribution of districts and guard posts]. Harbin: Heilongjiang renmin chubanshe.

Swann, N. L., 1950. Food and money in ancient China: The earliest economic history of China to $A D$ 25: Han Shu 24 with related texts, Han Shu 91 and Shih-Chi 129. Princeton, NJ: Princeton University Press.

Thote, A. 2003. "Lacquer craftsmanship in the Qin and Chu kingdoms: Two contrasting traditions (late 4th to late 3rd century BC)." Journal of East Asian Archaeology 5.1, 337-374.

van Ess, H. 1993. Politik und Gelehrsamkeit in der Zeit der Han (202 v. Chr.-220 n. Chr.): Die Alttext/Neutext-Kontroverse. Wiesbaden: Harrassowitz.

-. 2012. "The ethos of the envoy and his treatment by the enemy in Han history." Crossroads 5, 27-43.

-. 2014. Politik und Geschichtsschreibung im alten China: Pan-Ma i-t'ung 班馬異同. 2 vols. Wiesbaden: Harrassowitz.

von Glahn, R. 2016. The economic history of China: From antiquity to the nineteenth century. Cambridge: Cambridge University Press.

-. 2020. "Modalities of the fiscal state in imperial China." Journal of Chinese History 中國歷史學刊 4.1, 1-29.

Wagner, D. B. 2001. The state and the iron industry in Han China. Copenhagen: Nordic Institute of Asian Studies.

Wang, H. 2004. Money on the Silk Road: The evidence from eastern Central Asia to C. AD 800, including a catalogue of the coins collected by Sir Aurel Stein. London: British Museum Press.

-. 2007. "Official salaries and local wages at Juyan, north-west China, first century BCE to first century CE." In J. Lucassen (ed.), Wages and currency: Global comparisons from antiquity to the twentieth century, 59-76. Bern: Peter Lang. 
Wang Wei 王偉. 2014. “Jihu’ yu ‘jianhu’: Liye Qin jian suojian Qianling bianhu shuliang” “積戶” 與 “見戶”: 里耶秦簡所見遷陵編戶數量 [“Collected Households' and 'Actual Households': Household Numbers in the Qin Documents from Liye]. Sichuan wenwu 四川文物, no. 2, 6267.

Wang Zijin 王子今. 2018. “Dong Han Luoyang de guojihua shichang” 东汉洛阳的国际化市场 [The internationalization of the market in Luoyang during Later Han times]. Zhongyuan wenhua yanjiu 中原文化研究, no. 1, 15-21.

Watson, B. 1993. Records of the Grand Historian: Han dynasty II. Revised ed. New York, NY: Columbia University Press.

Wilbur, C. M. 1943. Slavery in China during the Former Han dynasty, 206 BC-AD 25. Chicago, IL: Field Museum of Natural History.

Xie, Y. and M. Brown. 2015. "Between heaven and earth: Dual accountability in Han China." Chinese Journal of Sociology 1.1, 56-87.

Xu Jianchang 许建强 and Qiu Xuefeng 邱雪峰. 2014. “Anhui Shouxian Shouchun zhen jisheng fuwu zhan Dong Han mu yiwu ji xiangguan wenti” 安徽寿县寿春镇计生服务站东汉墓遗物 及相关问题. [On the finds from a Later Han tomb found at the childbirth service station site in Shouchunzhen, Shouxian, Anhui, and related questions]. Dongnan wenhua 东南文化, no. 3, 46-52.

Yamada, Katsuyoshi 山田勝芳. 1993. Shin Kan zaisei shūnyū no kenkyū 秦漢財政収入の研究 [A study on Qin and Han fiscal revenue]. Tokyo: Kyūko shoin.

Yantie lun jiaozhu 鹽鐵論校注 [The Discourses on Salt and Iron with collated commentaries]. 1992. Composed by Huan Kuan 桓寬 (first century BCE). Commentaries compiled by Wang Liqi 王利器. Beijing: Zhonghua shuju.

Yang, L. S. 1957. "Economic justification for spending: An uncommon idea in traditional China." Harvard Journal of Asiatic Studies 20.1/2, 36-52.

Yates, R. D. S. 2014. "The changing status of slaves in the Qin-Han transition." In Y. Pines, G. Shelach, L. Falkenhausen, and R. D. S. Yates (eds.), Birth of an empire: The state of Qin revisited, 206-223. Berkeley, CA: University of California Press.

Yili zhushu 仪礼注疏 [Annotated edition of the Book of Etiquette and Ceremonial]. 1999. Composed by Zheng Xuan 鄭玄 (127-200 CE). Edited by Li Xueqin 李学勤. Beijing: Beijing daxue chubanshe.

Yu Xi 喻䂀 and Li Lingfu 李令福. 2012. “Xi Han Changling yi de shezhi ji qi yingxiang” 西汉长陵邑的设置及其影响 [The foundation of the town of Changling and its impact]. Shaanxi Shifan Daxue xuebao 陕西师范大学学报 41.2, 86-91.

Yü, Y. 1967. Trade and expansion in Han China: A study in the structure of Sino-barbarian economic relations. Berkeley CA: University of California Press.

-. 1977. "Han China." In K. C. Chang (ed.), Food in Chinese culture: Anthropological and historical perspectives, 53-83. New Haven, CT: Yale University Press.

Zheng, Y. 2008. "Concerning the viewers of Han mortuary art." In N. N. Richard (ed.), Rethinking recarving: Ideals, practices, and problems of the "Wu family shrines" and Han China, 92109. Princeton, NJ: Princeton University Art Museum.

Zhongguo shehui kexueyuan kaogu yanjiusuo Hancheng dui 中国社会科学院考古研究所汉城对, ed. 1994. “Han Chang'an cheng yaozhi fajue baogao” 汉长安城害址发掘报告 [Excavation report of the kiln sites of Han Chang'an]. Kaogu xuebao 考古学报, no. 1, 99-129.

Zhou Supin 周苏平 and Wang Zijin 王子今. 1985. “Han Chang’an cheng xibeiqu taoyong zuofang yizhi” 漢長安城西北區陶俑作坊遺址 [Finds from a production site of ceramic figurines in the northwestern part of the Han-era city of Chang'an]. Wenbo 文博, no. 3, 1-4. 